Notre Dame Law School

NDLScholarship

Journal Articles

Publications

2010

\title{
Shareholder Ownership and Primacy
}

Julian Velasco

Notre Dame Law School, jvelasco@nd.edu

Follow this and additional works at: https://scholarship.law.nd.edu/law_faculty_scholarship

Part of the Business Organizations Law Commons

\section{Recommended Citation}

Julian Velasco, Shareholder Ownership and Primacy, 2010 U. Ill. L. Rev. 897 (2010).

Available at: https://scholarship.law.nd.edu/law_faculty_scholarship/319

This Article is brought to you for free and open access by the Publications at NDLScholarship. It has been accepted for inclusion in Journal Articles by an authorized administrator of NDLScholarship. For more information, please contact lawdr@nd.edu. 


\title{
SHAREHOLDER OWNERSHIP AND PRIMACY
}

\author{
Julian Velasco*
}

According to the traditional view, the shareholders own the corporation. Until relatively recently, this view enjoyed general acceptance. Today, however, there seems to be substantial agreement among legal scholars and others in the academy that shareholders do not own corporations. In fact, the claim that shareholders do own corporations often is dismissed as merely a "theory," a "naked assertion," or even a "myth." And yet, outside of the academy, views on the corporation remain quite traditional. Most people-not just the public and the media, but also politicians, and even bureaucrats and the courts - seem to believe that the shareholders do, in fact, own corporations.

Why this disconnect? I believe that contemporary scholarship has done a better job of critiquing shareholder ownership than of disproving it. In this Article, I provide a defense of the traditional view by evaluating many of the arguments commonly raised against shareholder ownership and showing how they fall short. I then explain why the issue matters. As a theoretical matter, the issue of ownership is necessary to a proper understanding of the nature of the corporation and corporate law. As a practical matter, it is an important consideration in the allocation of rights in the corporation: if shareholders are owners, then the balance of rights will tip more heavily in their favor, and against others, than if they are not. Ownership may not settle any specific question of corporate governance, but it will make a significant difference in the analysis. Because the issue of ownership has the potential to shape all of corporate law and direct the very purpose of corporations, it is of utmost importance.

* Associate Professor of Law, Notre Dame Law School. J.D., 1994, Columbia University; B.S., 1991, Georgetown University. I would like to thank Stephen M. Bainbridge, Matthew J. Barrett, Lisa L. Casey, Ronald Colombo, and Brett McDonnell for their comments on earlier drafts; Dwight B. King, Patti Ogden, and Christopher O'Byrne for their expert research assistance; and Adam Lied and Shelby Lile for their excellent student assistance. 


\section{TABLE OF CONTENTS}

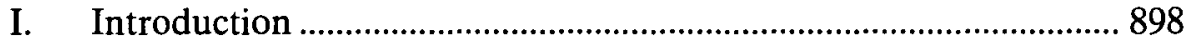

II. The Contemporary Critique ............................................................ 902

A. Is the Corporation Capable of Being Owned? ...........................903

B. Do Shareholders Have Control? .................................................907

C. Are Shareholders the Residual Claimants?...............................912

D. What About Options Theory? .................................................916

E. What About the Nexus-of-Contracts Theory? ………………....918

F. What About Stakeholders? ………….....................................924

III. The Affirmative Case...................................................................... 928

A. What Do Shareholders Own? ...................................................929

B. Do Shareholders Resemble Owners?........................................934

C. Do Shareholders Consider Themselves Owners?.......................938

IV. Why It Matters............................................................................... 939

A. Foundation of Shareholder Rights .........................................940

B. Shareholder Primacy ................................................................944

C. Director Accountability ............................................................948

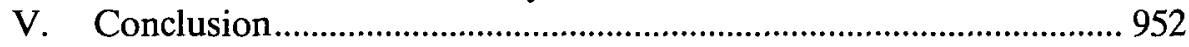

\section{INTRODUCTION}

"The principle that shareholders own the companies in which they invest - and are the ultimate bosses of those running them - is central to modern capitalism."

- Arthur Levitt Jr. ${ }^{1}$

According to the traditional view, the shareholders own the corporation. ${ }^{2}$ The corporation is a separate legal entity, with an identity distinct from that of its owners. Its governing body is the board of directors. The law authorizes the board of directors to manage the business and affairs of the corporation. However, as owners, the shareholders are entitled to elect directors. In addition, the law charges the directors with fiduciary duties to pursue the best interests of the shareholders. As for everyone else-such as employees, creditors, and customers - they are simply third parties who contract with the corporation at arm's length, much as they would with a sole proprietor. Everyone profits from mutually beneficial contracts, and society benefits from the opportunities that corporations create for its citizens.

1. Arthur Levitt Jr., How to Boost Shareholder Democracy, WALL ST. J., July 1, 2008, at A17.

2. For a general description of the traditional view, see Larry D. Soderquist \& Robert P. Vecchio, Reconciling Shareholders' Rights and Corporate Responsibility: New Guidelines for Management, 1978 DUKE L.J. 819, 819-25; see also Julian Velasco, The Fundamental Rights of the Shareholder, 40 U.C. DAVIS L. REV. 407, 437-39 (2006). 
Until relatively recently, the traditional view enjoyed general acceptance. $^{3}$ It is both simple and intuitive. The only real strain on the theory stems from the separation of ownership and control in public corporations. ${ }^{4}$ As a result, many have found it difficult to view public shareholders as owners in the same sense that sole proprietors are owners. Nevertheless, the traditional view has long proven resilient. For the most part, critics had accepted its premises and merely sought to promote a greater sense of corporate social responsibility. ${ }^{5}$ Today, however, there seems to be substantial agreement among legal scholars and others in the academy that shareholders do not own corporations. How did this come to pass?

It would take a major reconceptualization of the nature of the corporation to displace shareholders as owners. A few decades ago, the law and economics movement provided just that with its nexus-of-contracts, or contractarian, theory of the corporation. ${ }^{6}$ Under this view, the corporation is not a thing capable of being owned. Rather, it is a nexus of contracts among various parties. Each of the participants in the corporate enterprise makes an investment in the corporation in exchange for a contractual right to a return on his or her investment. As a result, shareholders have no special role in the corporation; their rights, like everyone else's, are limited to those provided by contract.?

Nevertheless, contractarians generally believe that the corporation should pursue shareholder interests for two reasons: first, because the shareholders have contracted for this; and second, because it is the efficient outcome. ${ }^{8}$ However, this pro-shareholder position does not follow inevitably from the basic premises. It is possible to accept some of the basic principles of the nexus-of-contracts theory and come to very different conclusions. Progressive corporate law scholars have done essentially that in developing a communitarian theory of the corporation. ${ }^{9}$ The fact that shareholders have no special status in the corporation led them to the conclusion that the corporation should be run, not in the interests of shareholders alone, but rather in the interests of society as a whole. ${ }^{10}$

Although they end up in very different places, contractarians and communitarians agree on the principle that shareholders do not own corporations. This is the view that currently enjoys general acceptance in

3. Levitt, supra note 1.

4. See Adolf A. Berle, JR. \& Gardiner C. Means, The Modern Corporation and PRIVATE PROPERTY 277-87 (1933).

5. See, e.g., David Millon, Communitarianism in Corporate Law: Foundations and Law Reform Strategies, in PROGRESSIVE CORPORATE LAW 1, 9-10 (Lawrence E. Mitchell ed., 1995).

6. See Frank H. Easterbrook \& Daniel R. Fischel, The Economic Structure of Corporate LAW 4-8 (1991); Michael C. JENSEN, A THEORY OF THE FiRm: Governance, RESIDUAL Claims, AND ORGANIZATIONAL FORMS 1-3 (2000).

7. See JENSEN, supra note 6 , at 1 .

8. See Velasco, supra note 2, at 445-49 (describing contractarian theory).

9. See, e.g., Millon, supra note 5; Margaret M. Blair \& Lynn A. Stout, A Team Production Theory of Corporate Law, 85 VA. L. REv. 247, 319-28 (1999); Kent Greenfield, New Principles for Corporate Law, 1 HASTINGs Bus. L.J. 87, 89 (2005).

10. See Velasco, supra note 2, at 455-56 (describing communitarian theory). 
scholarly circles. In fact, the claim that shareholders do own corporations often is dismissed as merely a "theory," a "naked assertion," 12 or even a "myth." 13 And yet, outside of the academy, views on the corporation remain quite traditional. Most people - not just the public ${ }^{14}$ and the media, ${ }^{15}$ but also politicians, ${ }^{16}$ and even bureaucrats ${ }^{17}$ and the courts ${ }^{18}-$ seem to believe that the shareholders do, in fact, own corporations. That the public, the media, and even politicians hold this view may not cause

11. Richard A. Booth, Who Owns a Corporation and Who Cares?, 77 CHI.-KENT L. REV. 147, 147 (2001).

12. Lynn A. Stout, Bad and Not-So-Bad Arguments for Shareholder Primacy, 75 S. CAL. L. REV. 1189,1190 (2002).

13. Theresa A. Gabaldon, Like a Fish Needs a Bicycle: Public Corporations and Their Shareholders, 65 MD. L. REV. 538, 538 (2006).

14. For a sampling of sources to which the public is likely to turn for information, see EDWARD T. KOCH ET AL., THE COMPLETE IDIOT'S GUIDE TO INVESTING 5 (3d ed. 2005) (“[C]ommon stock represents ownership in a company."); 3 THE NEw ENCYCLOPADIA BRITANNICA, MICROPÆDIA 647 (15th ed. 2002) ("The owners of the corporation in a legal sense are the shareholders...."); U.S. Dep't of Commerce, Minority Bus. Dev. Agency, Business Structure in Detail (Nov. 17, 2009), http://www.mbda.gov/?section_id=5\&bucket_id=123\&content_id=2383\&well=entire_page\&method= printer\#corp ("A corporation is a legal entity separate from the individuals who own or operate it. The shareholders, people who invest money in the company, are the owners of the corporation."); Wikipedia, Shareholder, http://en.wikipedia.org/wiki/Shareholder (last visited Jan. 23, 2010) ("A company's shareholders collectively own that company."); Investopedia, Shareholder, http://www. investopedia.com/terms/s/shareholder.asp (last visited Jan. 23, 2010) ("Shareholders are the owners of a company.").

15. See Stout, supra note 12, at 1190 ("This assertion ["that the public corporation 'belongs' to its shareholders"] is frequently employed by commentators in the popular media and business press to justify shareholder primacy.").

16. See, e.g., Interview by Larry Kudlow with President George W. Bush, (May 8, 2006), http:// kudlowsmoneypolitics.blogspot.com/2006/05/my-interview-with-president-bush.html ("PRESIDENT BUSH: .... [P]roxies are sometimes very difficult to understand ... . In my view, there ought to be a very straightforward, transparent explanation to the owners of the company-the shareholders-and let them come to their own conclusions.") (alteration in original); Letter from Senator Chris Dodd et al. to Christopher Cox, Chairman, U.S. Sec. \& Exch. Comm'n (Nov. 1, 2007) (on file with author), available at http://dodd.senate.gov/index.php?q=node/4113 ("Shareholders are the owners of a public company and have a right to meaningfully participate in electing directors ....").

17. See, e.g., "Options Backdating": Hearing Before the S. Comm. on Banking, Housing \& Urban Affairs, 109th Cong. 2 (2006) (statement of Christopher Cox, Chairman, U.S. Sec. \& Exch. Comm'n), available at http://banking.senate.gov/public/index.cfm?FuseAction=Files.View\&FileStore_id= 51e26ade-2d6b-4dfc-9b89-64484a472e77 ("The purpose of the new executive compensation rules is to make the CEO's pay understandable to the shareholders who own the company."); Nominations of: Mary Schapiro, Christina D. Romer, Austan D. Goolsbee, Cecilia E. Rouse, and Daniel K. Tarullo: Hearing Before the S. Comm. on Banking, Housing \& Urban Affairs, 111th Cong. 92 (2009) (Mary Schapiro responding to a written question from Sen. Carl Levin) ("A central tenet of our market system is that shareholders are the owners of the company in which they hold shares, and they should have a way to hold their representatives-members of the board of directors-accountable for their actions."); Alan Greenspan, Chairman, Fed. Reserve Bd., Commencement Address at the Wharton School, University of Pennsylvania, Philadelphia, Pennsylvania (May 15, 2005), available at http://www.federalreserve.gov/boarddocs/speeches/2005/20050515/default.htm ("The Sarbanes-Oxley Act of 2002 ... importantly reinforced the principle that shareholders own our corporations and that corporate managers should be working on behalf of shareholders ...."); see also U.S. DEP'T OF THE TREASURY, FACT SHEET: ENSURING INVESTORS HAVE A SAY ON PAY (2009), http://www.treas.gov/ press/releases/reports/fact_sheet_say\%20on\%20pay.pdf (repeatedly referring to shareholders as owners of companies).

18. See, e.g., N. Am. Catholic Educ. Programming Found., Inc. v. Gheewalla, 930 A.2d 92, 101 (Del. 2007) (quoting Malone v. Brincat, 722 A.2d 5, 9 (Del. 1998)); Stokes v. Cont'l Trust Co., 78 N.E. 1090, 1093 (N.Y. 1906). 
academics much concern. However, that bureaucrats and the courtsthe legal experts - do is significantly more troubling.

Why this disconnect? I believe that contemporary scholarship has done a better job of critiquing shareholder ownership than of disproving it. Given its historical significance as well as its current widespread acceptance outside the academy, the traditional view is the starting point for discussion, and its critics bear the burden of persuasion. The arguments that have been raised against it thus far fall short. They may manage to raise the reader's level of discomfort with the traditional view, but they do not require her to reject it. In reality, they are arguments that shareholders should not be owners rather than that they are not owners. The nexus-of-contracts theory has achieved the success it has among scholarly circles by providing a viable alternative-a holistic account of the corporation that is both coherent and plausible. However, it has not proven compelling enough to displace the traditional view outside of the academy.

In this Article, I provide a defense of the traditional view by evaluating many of the arguments commonly raised against shareholder ownership. In Part II, I consider the arguments that form the core of the contemporary critique of the traditional view and show how each of the arguments falls short. In Part III, I turn to additional arguments often leveled against the traditional view that allow me to develop an affirmative case - that the shareholders really do own the corporation and that it makes sense to consider them owners. Throughout Parts II and III, I hope to demonstrate that corporate law generally is not only consistent with, but actually an embodiment of, the traditional view. Ultimately, I do not expect to prove to everyone's satisfaction that the traditional view is correct. However, I do hope to demonstrate that others have not established the opposite and that the traditional view remains viable. Thus, my goal is to rekindle an important debate in corporate law rather than to settle it.

This endeavor naturally leads to the question of why: why does shareholder ownership matter? It matters on both a theoretical and practical level. As a theoretical matter, the issue of ownership is necessary to a proper understanding of the nature of the corporation and corporate law. As a practical matter, it is an important consideration in the allocation of rights in the corporation: if shareholders are owners, then the balance of rights will tip more heavily in their favor, and against others, than if they are not. This is particularly important at a time when corporate governance is undergoing serious reconsideration. Proposals for the expansion of shareholder rights, including majority voting, proxy access, and say-on-pay, as well as caps on executive compensation, have been dominating the headlines. ${ }^{19}$ The issue of shareholder ownership will

19. See, e.g., Clark S. Judge \& Richard Torrenzano, Capitalism by Proxy Fight, WALL ST. J., Nov. 23, 2009, at A21; Jeffrey McCracken \& Kara Scannell, Fight Brews As Proxy Access Nears, WALL ST. 
have an important bearing on these debates. Thus, regardless of the normative desirability of shareholder rights, the issue is an important one. Advocates on both sides should be concerned, albeit for very different reasons.

In Part IV, I address some of the consequences of shareholder ownership. First, I argue that shareholder rights would be stronger and more secure if based on property than on contract. Next, I argue that, if shareholders are owners, then the purpose of the corporation must be to pursue their interests, and the goal of corporate governance must be to effectuate their collective will-not immediately and in every particular, of course, but generally and ultimately. In other words, shareholder primacy becomes the fundamental value of corporate governance, in terms of both end and means. Finally, I argue that, if shareholders are owners, then accountability for the directors who are charged with managing the business on their behalf is an appropriate and indispensible aspect of corporate law. I do not maintain that ownership will settle any specific question of corporate governance. Rather, my claim is that it will make a significant difference in the analysis. Because the issue of ownership has the potential to shape all of corporate law and direct the very purpose of corporations, it is of utmost importance.

In Part V, I conclude with a more detailed account of the traditional view. One problem with an endeavor such as the one attempted in this Article is that it must deal discreetly with arguments that ultimately are interrelated. In order to reintegrate the arguments, I attempt to synthesize various claims made throughout this Article in the form of an easily digestible narrative. In doing so, I hope to demonstrate not only that the traditional view is perfectly viable, but also why it is reasonable for those outside of the academy to adhere to it.

\section{THE CONTEMPORARY CRITIQUE}

In this Part, I consider the arguments that form the core of the contemporary critique of the traditional view. First, I argue that the corporation is capable of being owned. Then I argue that shareholders have the type of control that could be expected of co-owners. Next, I examine the status of shareholders as the residual claimants. Thereafter, I demonstrate that options theory does not undermine shareholder ownership. Finally, I turn to competing theories of the firm: first contractarian theory and then communitarian theory. I argue that, although they can be helpful in understanding the complexities of the modern corporation,

J., Aug. 26, 2009, at C1; Gretchen Morgenson, When a Company Tries It, a 'Say on Pay' Works, N.Y. TIMES, May 17, 2009, at B1; Restraints on Executive Pay: Attacking the Corporate Gravy Train, THE ECONOMIST, May 30, 2009, at 71-73; see also Shareholder Bill of Rights Act of 2009, S. 1074, 111th Cong. (as referred to the S. Comm. on Banking, Housing, and Urban Affairs, May 19, 2009). 
these theories do not displace the traditional view in terms of descriptive accuracy.

\section{A. Is the Corporation Capable of Being Owned?}

A common claim among contemporary corporate law scholars is that the corporation is not a thing capable of being owned. If this is true, the shareholders not only do not, but cannot, own the corporation. This facial challenge to the traditional view is most often made by contractarians. Professor Stephen Bainbridge explains as follows:

[C]ontractarians reject the idea that the firm is a thing capable of being owned.... Someone owns each of [the various factors of production in the corporation], but no one owns the nexus itself. To be sure, most theories of the firm agree, shareholders own the residual claim on the corporation's assets and earnings.... Yet, ownership of the residual claim is not the same as ownership of the firm itself..$^{20}$

This claim is a fairly narrow one. Contractarians generally accept that there are things capable of being owned; they simply deny that the corporation is one of them..$^{21}$

This claim is not so much an argument as it is a conclusion. More precisely, it states only that "ownership is not a meaningful concept in nexus of contracts theory." 22 In other words, given the contractarian description of the corporation, it is inappropriate to describe the shareholder interest as an ownership claim. Of course, this conclusion depends entirely upon the accuracy of the contractarian account, which will be taken up in a later Section. ${ }^{23}$

An argument that shareholders are not owners because the corporation is not a thing capable of being owned would be circular. It also would be rather weak - at least if one were to accept the concept of ownership generally. To be sure, the corporation is not a tangible item to which the shareholder can physically point and say, "this is mine." However, ownership interests exist in intangible items as well. For example, the law recognizes ownership interests in various forms of intellectual property such as copyrights, patents, and trademarks. ${ }^{24}$ More importantly, the law also recognizes ownership interests in other forms of business

20. Stephen M. Bainbridge, Director Primacy: The Means and Ends of Corporate Governance, 97 Nw. U. L. REV. 547, 564-65 (2003) (footnote omitted); see also Eugene F. Fama, Agency Problems and the Theory of the Firm, 88 J. POL. ECON. 288, 290 (1980).

21 . The position taken by contractarians clearly is meant to evoke the realist account of property-as relations among people rather than as thing-ownership. However, it does not actually subscribe to that theory by minimizing the significance of property. To the contrary, it recognizes the importance of property as a prerequisite to contract. Thus, I interpret the contractarian claim not as denying property but merely as denying corporations the status of property. The broader property claim of the realists is considered in the second half of this Section.

22. Stephen M. Bainbridge, In Defense of the Shareholder Wealth Maximization Norm: A Reply to Professor Green, 50 WASH. \& LEE L. REV. 1423, 1427 (1993).

23. See infra Part 1.E.

24. 15 U.S.C. $\S \S 1052,1057$ (2006); 17 U.S.C. $\S \S 102,201$ (2006); 35 U.S.C. $\S \S 101,261$ (2006). 
organization, such as sole proprietorships and partnerships. ${ }^{25}$ There is no reason why the corporate form uniquely would make a business incapable of being owned.

Scholars often warn against reification of the corporation. ${ }^{26}$ The concern is that "reification is a device for making something that is in fact complex seem simple, and that can be dangerous." 27 However, even critics admit that "reification may sometimes be a useful device"28 and that "it would be difficult to communicate effectively without it." 29 Thus, the problem is not reification per se, but oversimplification. Although we should proceed with caution, there is no need to abandon reification altogether. The traditional view is perfectly capable of dealing with the fact that separate entity status is a legal fiction and that there are real people with real interests involved. Reification of the corporation does not cause insurmountable problems. In any event, the corporation can be a thing that is capable of being owned-if the law so provides.

The claim that the corporation is not a thing capable of being owned also can be construed much more broadly to raise fundamental questions about the concept of ownership. A property law scholar might ask whether anything is capable of being owned, and whether ownership is a meaningful concept at all. Of course, that is a topic far beyond the scope of this Article. Nevertheless, it should be considered, if only briefly.

The traditional account of property in the common law was that property was a thing that was owned by a person..$^{30}$ An owner had complete dominion over his property, subject only to specific legal restrictions. Such restrictions were viewed as exceptions to the general rule and, implicitly at least, every regulation required justification.

An extreme version of this position was set forth by William Blackstone. In his Commentaries, he defined property as "that sole and despotic dominion which one man claims and exercises over the external things of the world, in total exclusion of the right of any other individual in the universe." 31 Of course, the traditional view of property was never quite so absolute. Even Blackstone realized that there were numerous exceptions that whittled down the rights of ownership substantially. ${ }^{32}$

25. REVISED UNIF. P'SHIP ACT $\$ 202$ (a) (1997).

26. See, e.g., William A. Klein \& John C. Coffee, JR., Business Organization AND FinANCE: Legal AND ECONOMIC PRINCIPLES 117-18 (10th ed. 2007); G. Mitu Gulati et al., Connected Contracts, 47 UCLA L. REV. 887, 888-93 (2000).

27. KLEIN \& COFFEE, supra note 26 , at 118 ; see also Gulati et al., supra note 26 , at 890 ("Depending on its uses, however, reification can also be a barrier to effective analysis.").

28. KLEIN \& COFFEE, supra note 26 , at 118.

29. Gulati et al., supra note 26 , at 890 .

30. BLACK'S LAW DICTIONARY 1335-36 (9th ed. 2009)

31. 2 WILLIAM BLACKSTONE, COMMENTARIES *2.

32. See ForREST MCDONALD, NovUs ORdo SEClorum: THE INTELlECTUAL ORIGINS OF THE CONSTITUTION 13 (1985) ("Blackstone's sweeping definition... overstated the case; indeed, he devoted the succeeding 518 pages of book 2 of his Commentaries ... to qualifying and specifying the exceptions to his definition."). 
Nevertheless, some legal scholars found the traditional account of property difficult to accept. They saw property rights as much more limited and fluid than Blackstone suggested.

In the early twentieth century, legal realists developed their own theory of property. They described it as a "bundle of rights." ${ }^{33}$ The purported owner does not have complete dominion over an asset, but only certain rights with respect to it. Others may have rights with respect to the asset as well. In other words, property rights are not absolute. As a result, regulation of property does not require much justification: limits are to be expected. ${ }^{34}$

While the realist account of property seemed to overcome some of the shortcomings of the traditional account, it had certain problems of its own. As Professor Thomas Grey has noted, "[t]he substitution of a bundle-of-rights for a thing-ownership conception of property has the ultimate consequence that property ceases to be an important category in legal and political theory." 35 While Grey did not see this as a problem, it certainly makes discussion of property difficult. If there is no such thing as property, then of course the corporation cannot be owned. However, it clearly is not the case that property is a meaningless concept under existing law; to the contrary, property is a constitutionally protected right. ${ }^{36}$ Thus, I assume in this Article that the disintegration of property is less than complete and that the concept of property is meaningful.

Logically, neither the traditional nor the realist account of property necessarily leads to any specific conclusions. Thing-ownership, for example, is generally associated with broad rights and limited regulation. However, because property rights have always been understood to be subject to legal restrictions, thing-ownership can be reconciled quite easily with a world of pervasive regulation. Likewise, the bundle-of-rights is generally associated with limited rights and expansive regulation. That said, if people are understood to have a property interest in each right in the bundle, then even minor regulation could be considered a compensa-

33. See A.M. Honoré, Ownership, in OXFORD ESSAYS IN JURISPRUDENCE 107, 113 (A.G. Guest ed., 1961); Wesley Newcomb Hohfeld, Some Fundamental Legal Conceptions as Applied in Judicial Reasoning, 23 YALE L.J. 16, 21-24 (1913); see also JOSEPH WILliAM SINGER, INTROduction to PROPERTY 2-3 (2d ed. 2005).

34. See Thomas W. Merrill \& Henry E. Smith, What Happened to Property in Law and Economics?, 111 YALE L.J. 357, 365 (2001).

[T] he motivation behind the realists' fascination with the bundle-of-rights conception was mainly political. They sought to undermine the notion that property is a natural right, and thereby smooth the way for activist state intervention in regulating and redistributing property. If property has no fixed core of meaning, but is just a variable collection of interests established by social convention, then there is no good reason why the state should not freely expand or, better yet, contract the list of interests in the name of the general welfare.

Id. at 365 (footnote omitted).

35. Thomas C. Grey, The Disintegration of Property, in NOMOS XXII: PROPERTY 69, 81 (J. Roland Pennock \& John W. Chapman eds., 1980).

36. U.S. CONST. amends. V, XIV, § 1 . 
ble taking. ${ }^{37}$ In the end, both accounts can accommodate any type of property interest.

Although the realist account of property has been the dominant view in the academy for quite some time, it has had difficulty gaining acceptance among ordinary people. As even proponents of the bundle-ofrights theory will admit, the traditional account is stubborn. ${ }^{38}$ Recently, there have been scholars willing to challenge the new orthodoxy. ${ }^{39}$ For example, in a series of insightful articles, Professors Thomas Merrill and Henry Smith have argued that the in rem nature of certain rights is necessary for a proper understanding of property law..$^{40}$ Among the benefits of the traditional account are increased stability and reduced transaction costs, ${ }^{41}$ both of which are considered beneficial in the business world.

The traditional view of the corporation may seem more comfortable in the world of traditional property law. However, it has survived for decades in a world where the realist account is dominant. In fact, the traditional view of the corporation arguably is a better fit with the bundle-of-rights theory, which is perfectly comfortable with shareholders having certain rights normally associated with ownership and not others. The intangible nature of corporations is significantly less troubling when property means rights rather than things. In short, there is nothing in bundle-of-rights theory that prevents shareholders in particular from being considered owners. Shareholders' rights may not seem quite as robust as some other owners' rights, but one of the key insights of the realist account is that property rights are neither simple nor uniform. ${ }^{42}$

Perhaps the most satisfying defense of the corporation as property is the argument by analogy. The traditional view of the corporation can be considered perfectly viable because the corporation bears a strong family resemblance to another generally accepted form of property: the trust. In a trust, as in a corporation, there is a separation of ownership and control. In a trust, the beneficiary is the beneficial owner while control is given to the trustee, who is charged with managing the trust for the bene-

37. See Bruce A. ACKerman, Private Property ANd the CONSTitution 28 (1977) ("Whenever the state takes any user right out of Jones's bundle and puts it in any other bundle, private property should be understood to have been taken.").

38. See infra notes 216-20 and accompanying text.

39. See, e.g., J.E. Penner, The "Bundle of Rights" Picture of Property, 43 UCLA L. REv. 711, 714 (1996) (arguing "that this 'dominant paradigm' is really no explanatory model at all, but represents the absence of one").

40. See Thomas W. Merrill \& Henry E. Smith, Optimal Standardization in the Law of Property: The Numerus Clausus Principle, 110 YALE L.J. 1, 8 (2000) [hereinafter Merrill \& Smith, Numerus Clausus]; Thomas W. Merrill \& Henry E. Smith, The Property/Contract Interface, 101 COLUM. L. REV. 773, 777 (2001) [hereinafter Merrill \& Smith, Interface]; Merrill \& Smith, supra note 34, at 359.

41. See Merrill \& Smith, Numerus Clausus, supra note 40, at 24-25, 33-34; Merrill \& Smith, Interface, supra note 40, at 792-97; Merrill \& Smith, supra note 34, at 387.

42. The real issue under bundle-of-rights theory is whether others can be considered owners of the corporation as well, and that will be taken up in a later Section. See infra text accompanying note 148. 
fit of the beneficiaries. ${ }^{43}$ This is the essential framework of the corporation: the shareholders are the beneficial owners but control is given to the directors, who are charged with managing the corporation for the benefit of the shareholders. ${ }^{44}$ So, just as trust beneficiaries are the beneficial owners of the trust, so too the shareholders are the beneficial owners of the corporation.

Although the corporation has often been analogized to a trust, it is not literally a trust; it is sui generis. ${ }^{45}$ In fact, shareholders have more of the rights normally associated with ownership than do trust beneficiaries. Shareholders have a significant element of control in that they have the power to elect and remove directors, whereas trust beneficiaries generally do not have the power to select or remove trustees. In addition, shareholders get to vote on certain fundamental matters, whereas beneficiaries generally have no input. Thus, the corporation actually is less problematic as property than the trust.

In short, there is no logical reason why the law could not treat the corporation as the property of the shareholders. If there is any argument in the claim that the corporation is not capable of being owned, it is not that the law does not or cannot recognize an ownership interest in the corporation, but only that it should not.

\section{B. Do Shareholders Have Control?}

The most common argument against the traditional view is that shareholders cannot be considered the owners of the corporation because they lack the most important right of ownership: control. The logic is straightforward: "An owner has the power to control the property she owns." 46 Shareholders do not have control. Therefore, shareholders are not owners.

As we have seen in the previous Section, property law is not so simple. Ownership never conveys absolute control, ${ }^{47}$ and "rights associated with ownership can be unbundled or disaggregated." 48 In other words, control is not a binary issue. In fact, it is not even indispensible to ownership. Various property interests separate ownership from control. For example, in a lease, the lessor is the owner but the lessee has control over the asset for the term of the lease..$^{49}$ More significantly, in a trust, the beneficiaries are the beneficial owners but the trustee has control over the trust assets. Thus, even a complete absence of control would not be a

43. See RESTATEMENT (THIRD) TRUSTS § 2 (2003).

44. See Franklin A. GeVurTZ, CORPORATION LAW $\$ 3.1$, at 179-80 (2000).

45. See Velasco, supra note 2, at 438-39.

46. SINGER, supra note 33 , at 2.

47. Id. at 3 ("[P]roperty rights are limited to protect both the property and personal rights of others, as well as the interests of the community.").

48. Id.

49. Id. at 437 . 
sufficient basis to conclude that shareholders are not the owners of the corporation. However, shareholders are not completely lacking in control.

The control argument can take various forms. Scholars often focus on the fact that shareholders lack control over the assets of the corporation. Professor Margaret M. Blair, for example, has noted that "[o]wning shares of stock in a company does not mean shareholders can move themselves into a corner office, take the corporate jet out for a test flight, or order the company to hire their children." to direct the corporation and control its assets belongs to the directors. However, this is perfectly consistent with the traditional view. Shareholders should not be expected to have control over the business assets for the simple reason that they do not own them. Shareholders own the corporation; the corporation owns the business assets. Because directors are the parties authorized to manage the business, they are the ones with control over the corporate assets.

This system makes perfect sense. A business could not function if every owner had equal access to the business assets for personal use. Given the co-owners' shared interest in the assets, it is necessary to have some limits to access and rules for control. Business law provides for different forms of organization to meet different needs. A partnership, for example, allows co-owners to act independently (unless they agree otherwise). ${ }^{51}$ However, even partners are only entitled "to possess specific partnership property for partnership purposes." 52 A corporation, on the other hand, does not allow the co-owners to act independently (unless they agree otherwise).$^{53}$ Instead, shareholders act together to elect directors who are given control over the assets. Both methods are perfectly reasonable ways to allocate control when there are multiple owners. Others could be imagined. None should be deemed to undermine the ownership interest. Thus, shareholders do not lack control; they merely exercise their control indirectly, through elected representatives.

The control argument is more effective when it refers to control over the corporation itself. Professor Bainbridge makes the case that shareholders lack control over the corporation as follows:

[S]hareholder control rights are so weak that they scarcely qualify as part of corporate governance. Instead, corporate law vests the board of directors with a nonreviewable power of discretionary fiat. For example, under the Delaware code, shareholder voting rights are essentially limited to the election of directors, and the approval of charter or by-law amendments, mergers, sales of substantially all

50. Margaret M. Blair, OWNership and Control: Rethinking Corporate GOVERNANCE FOR THE TWENTY-FIRST CENTURY 34 (1995); see also Bainbridge, supra note 20, at 564 n.81; Stout, supra note 12 , at 1191 .

51. UNIF. P'SHIP ACT § 18(e) (1914); see also REVISED UNIF. P'SHIP ACT \& 401(f) (1997).

52. UNIF. P'SHIP ACT $\S 25(2)$ (a); see also REVISED UNIF. P'SHIP ACT $§ 401(\mathrm{~g})$.

53. MODEL BUS. CORP. ACT $\$ 7$ (2006). 
of the corporation's assets, and voluntary dissolution. As a formal matter, only the election of directors and amending the by-laws do not require board approval before shareholder action is possible. In practice, of course, even the election of directors, absent a proxy contest, is predetermined by the existing board nominating the next board.

These direct restrictions on shareholder power are supplemented by a host of other rules that indirectly prevent shareholders from exercising significant influence over corporate decisionmaking. Three sets of statutes are especially noteworthy: (1) disclosure requirements pertaining to large holders, (2) shareholder voting and communication rules, and (3) insider trading and short swing profits rules. These laws affect shareholders in two respects. First, they discourage the formation of large stock blocks. Second, they discourage communication and coordination among shareholders. As a result, shareholders neither own sufficient stock to exercise meaningful control over the firm nor do they band together to exercise such control. ${ }^{54}$

Although Bainbridge may overstate the matter somewhat, it is difficult to deny that direct shareholder control over the corporation is quite limited in fact..$^{55}$

Of course, this limited control in fact is true only of public corporations with dispersed shareholders. In closely held corporations, shareholders often have significant control in fact. And, when there is only one shareholder - as is the case with wholly owned subsidiaries of public corporations, for example - the shareholder has complete control in fact. Thus, it is not the corporate form, but rather dispersed ownership, that reduces shareholder influence.

Even in public corporations, however, shareholders are able to exercise a great deal of influence. For example, consider the election of directors. Because of plurality voting, it long has been impossible for shareholders to remove directors without a proxy contest. ${ }^{56}$ Nevertheless, directors often have found it difficult to remain on the board in the face of a significant minority of withhold votes. ${ }^{57}$ Thus, shareholders arguably have had more power in fact than the law and circumstances suggest they should..$^{58}$ Moreover, in recent years, shareholders have become a much more powerful voice in corporate governance. With respect to

54. Bainbridge, supra note 20 , at 569-70 (footnotes omitted).

55. See Julian Velasco, Taking Shareholder Rights Seriously, 41 U.C. DAVIS L. REV. 605, 609-20 (2007).

56. See id, at $611-12$.

57. See, e.g., Ronald Grover \& Tom Lowry, Now It's Time to Say Goodbye: How Disney's Board Can Move Beyond the Eisner Era, Bus. WK., Mar. 15, 2004, at 31 (discussing election at 2004 Annual Meeting of Walt Disney Co., where forty-three percent of shareholders withheld support for Chairman and CEO Michael D. Eisner, leading to his replacement as Chairman).

58. To my knowledge, no one has suggested that shareholders should be able to elect or remove directors by less than a majority vote. 
elections, their demands for reform have led many corporations to replace the plurality voting standard with a majority voting standard, or at least a modified plurality voting standard. ${ }^{59}$ This change will make it significantly easier for shareholders to remove directors in the future. Thus, shareholder influence should not be underestimated. ${ }^{60}$

It is true that, with rare exceptions, each individual shareholder of a public corporation is virtually powerless. That being said, this is entirely appropriate because, with rare exceptions, each individual shareholder owns only a very small percentage of a public corporation. Thus, under the traditional view, he or she ought to have only a very small say in the corporation. However, shareholders in the aggregate have significant control over the corporation. It is undeniable that, if they work together, public shareholders can remove existing directors and elect new directors of their choosing. Thus, the argument that shareholders lack control rests not on actual powerlessness, but primarily on the existence of presumably insurmountable collective action and coordination problems.

To be sure, economic incentives often make it difficult for individual shareholders to become engaged in corporate governance. However, the incentives are not nearly so problematic for institutional shareholders, who typically have much larger holdings. ${ }^{61}$ In fact, a significant part of the problem may be the existence of artificial obstacles created by laws that were intended to help shareholders. ${ }^{62}$ One important example is the federal proxy rules, which were intended to help shareholders exercise their voting rights but which also prevent them from coordinating with each other freely. ${ }^{63}$ Thus, it may not be fair to say that shareholders lack control. Rather, it may be more accurate to say that federal law prevents shareholders from exercising their ownership rights under state law. It would be inappropriate to deny shareholders ownership under state law because of the unintended consequences of federal law.

Moreover, shareholders do not need to band together in order to exercise control. Instead, the market for corporate control can unite them. ${ }^{64}$ When dissatisfied shareholders sell their shares, there is a negative impact on the company's stock price. This makes the company more vulnerable to a hostile takeover. When the price is low enough, third

59. See Claudia H. Allen, Study of MAJority Voting In DiRector Elections vii (2007), http://www.ngelaw.com/files/upload/majoritystudy111207.pdf.

60. Of course, the real response of the traditional view would be that if shareholders lack the type of control that is associated with ownership, then it ought to be given to them. However, the point in the text is that shareholders are not as lacking in control as is often suggested.

61. See Velasco, supra note 55, at 623-24.

62. See id. at 609-21.

63. See Bernard S. Black, Agents Watching Agents: The Promise of Institutional Investor Voice, 39 UCLA L. REV. 811, 823-24 (1992); Bernard S. Black, Shareholder Passivity Reexamined, 89 MICH. L. REV. 520, 536-41 (1990) [hereinafter Black, Shareholder Passivity].

64. See Henry G. Manne, Mergers and the Market for Corporate Control, 73 J. PoL. Econ. 110, 112-14 (1965); see also Fred S. McChesney, Manne, Mergers, and the Market for Corporate Control, 50 CASE W. RES. L. REV. 245 (1999). 
parties may be willing to step in and buy the corporation. In doing so, the acquirer will be solving the shareholders' coordination and collective action problems by presenting them with a simple decision: to sell or not to sell. In a successful takeover, at least, the shareholders are in control: the public shareholders decide whether to sell the company, and the successful acquirer decides whether to replace existing management.

Finally, critics may argue that the extent of the directors' power and discretion is problematic for the traditional view. Corporate law statutes almost uniformly provide that " $\mathrm{t}]$ he business and affairs of every corporation ... shall be managed by or under the direction of a board of directors ...." Courts tend to read this language expansively: director authority is said to be "original and undelegated," 66 and directors are rerequired to exercise their own business judgment rather than follow the shareholders' instructions. ${ }^{67}$ Moreover, as long as directors are not engaged in self-dealing, their decisions will be upheld "if they can be attributed to any rational business purpose."68 All of this may seem inconsistent with shareholder ownership. ${ }^{69}$ However, the breadth of director authority must be put into context. Shareholders elect directors and directors have a fiduciary duty to manage the business in the best interests of the shareholders. Thus, the directors are the elected representatives of the shareholders. ${ }^{70}$ Under the traditional view, the board of directors is not supposed to be at odds with shareholders; rather, it is supposed to be an institution that enables dispersed shareholders to exercise their control rights indirectly. ${ }^{71}$ It may fall short of the ideal, as most institutions do, but that cannot be the basis for denying the shareholders' own-

65. Del. CODE ANN. tit. $8, \S 141$ (a) (2001); see also MODEL Bus. CORP. ACT $\S 8.01$ (b) (2008).

66. See N. Assurance Co. v. Rachlin Clothes Shop, Inc., 125 A. 184, 188 (Del. 1924) (quoting Hoyt v. Thompson's Ex'r, 19 N.Y. 207, 216 (1859) (internal quotation marks omitted)); Manson v. Curtis, 119 N.E. 559, 562 (N.Y. 1918).

67. See People ex rel. Manice v. Powell, 94 N.E. 634, 637 (N.Y. 1911); cf. Grimes v. Donald, 673 A.2d 1207, 1214 (Del. 1996) (explaining that directors cannot abdicate responsibilities for managing business).

68. 2 MODEL BUS. CORP. ACT ANN. $\$ 8.31 \mathrm{cmt}$, at 8-232 (2009) (citing Sinclair Oil Corp. v. Levien, 280 A.2d 717, 720 (Del. 1971)); see also In re Walt Disney Co. Derivative Litig., 906 A.2d 27, 74 (Del. 2006).

69. A related argument would be that it is more accurate to describe the directors as owners than the shareholders. This might find support in judicial statements such as that made by the New York Court of Appeals in People ex rel. Manice v. Powell, 98 N.E. 634, 637 (N.Y. 1911): "The corporation is the owner of the property, but the directors in the performance of their duty possess it, and act in every way as if they owned it." Such statements are perfectly consistent with the traditional view, which holds that shareholders own the corporation, the corporation owns the business assets, and the directors manage the business. However, the final portion of the quoted language is somewhat an overstatement. Directors cannot "act in every way as if they owned" the corporate assets. They cannot, for example, take them for personal use or consumption. Rather, their use of corporate property is limited to "the performance of their duty." In other words, they are like trustees, which is the traditional view. In fact, the opinion makes this clear in context. See id.

70. According to the Delaware Supreme Court, "[t]he power of managing the corporate enterprise is vested in the shareholders' duly elected board representatives." MM Cos. v. Liquid Audio, Inc., 813 A.2d 1118, 1126 (Del. 2003) (emphasis added) (citing Paramount Commc'ns, Inc. v. Time, Inc., 571 A.2d 1140, 1154 (Del. 1989)).

71. See Velasco, supra note 2 , at $440-42$. 
ership claim. To the contrary, it should be the basis for legal reform to better align the institution with its purpose.

In short, shareholders do not lack the control that would be expected of owners. Their rights are perfectly consistent with joint ownership. Shareholders elect directors to run the business in their interests. In doing so, they exercise their control rights indirectly. Little more could be expected and nothing more could be demanded. Each individual shareholder cannot have the control rights of a sole proprietor. However, shareholders collectively do.

\section{Are Shareholders the Residual Claimants?}

One of the main economic justifications often given for shareholder primacy is that shareholders are the residual claimants. ${ }^{72}$ Because only they bear the risk of every business decision - in terms of both the upside and downside potential - they alone have the incentives to maximize wealth. By comparison, fixed claimants will be too risk averse because they will not share in additional profits. ${ }^{73}$

Not everyone finds this justification persuasive. ${ }^{74}$ For example, Professor Lynn Stout has argued that "shareholders are only one of several groups that can be described as 'residual claimants' or 'residual risk bearers,' in the sense that they expect to enjoy benefits (and sometimes to endure burdens) beyond those provided in their explicit contracts." 75 Because she believes that shareholders are not the sole residual claimants, she concludes that they do not deserve a privileged position in the corporation. ${ }^{76}$

The problem with Stout's argument lies in its capacious definition of the term "residual claimant." She improperly defines it to include anyone who expects to enjoy benefits and endure burdens beyond those provided in their explicit contracts. This definition is too broad. ${ }^{77}$ It counts almost anything as a benefit or burden. For example, the possibility of raises and job security are considered relevant risks to the em-

72. See Stout, supra note 12 , at 1192 ("[W]hile shareholders may not be the owners of the corporation, they are at least its sole residual claimants.").

73. See Frank H. Easterbrook \& Daniel R. Fischel, Voting in Corporate Law, 26 J.L. \& ECON. 395, 403-04 (1983).

74. See, e.g., Jonathan R. Macey, An Economic Analysis of the Various Rationales for Making Shareholders the Exclusive Beneficiaries of Corporate Fiduciary Duties, 21 STETSON L. REV. 23, 31 (1991) (describing residual claimant argument as "incomplete" because "[o]ther claimants face the realistic prospect of tangible loss if decisions ... . are not made with their interests in mind"). Macey's concern is essentially about the vicinity of insolvency, where corporate decisions can affect creditors with respect to their contractual rights. This is considered below.

75. Stout, supra note 12 , at 1194.

76. See id. at 1208 ("[T]he argument that the shareholders 'own' the firm and the argument that shareholders are the firm's sole residual claimants-are bad arguments.").

77. Ironically, Stout's definition is also too narrow in that it could actually exclude shareholders. The shareholders' "explicit contract" entitles them to whatever profits there may be. There are no benefits or burdens that can lie beyond such a claim. Thus, under her definition, shareholders should not count as residual claimants. 
ployee under her approach. ${ }^{78}$ Every stakeholder risks similar indirect benefits and burdens depending upon the health of the company: for creditors, in the risk of default; for customers, in the value of a warranty; for local government, in tax receipts and local employment. Thus, every claimant can be characterized as a residual claimant under Stout's analysis. Essentially, Stout's claim is that everyone bears the risk that their benefits will not match those promised by the corporation - whether because they exceed the promise or fall short. This is true - in fact, everyone bears risk at all times with respect to almost everything - but it is not the relevant consideration. Although everyone's claim is at risk, not everyone is a residual claimant. A residual claimant is one who is "entitle $[\mathrm{d}]$... to whatever remains after the firm has met its explicit obligations and paid its fixed claims." 79 Only shareholders meet this definition. ${ }^{80}$

Because shareholders are residual claimants, the corporation's profits and losses affect their wealth directly. The marginal dollar of profit or loss falls on them. Stout disagrees. She notes that, "as a legal matter, shareholders of a public corporation are entitled to receive nothing from the firm unless and until the board of directors decides that they should receive it." ${ }^{\text {"1 }}$ This observation is accurate but irrelevant because the corporation's decision to pay dividends is itself largely irrelevant. ${ }^{82}$ If a company retains its earnings instead of paying dividends, its stock price will increase, and this will benefit the shareholders. Likewise, if a company loses money, its stock price will decrease, and this will harm the shareholders. ${ }^{83}$ Shareholder wealth is not dependent upon dividends. In fact, shareholders may prefer not to receive dividends for tax reasons. ${ }^{84}$

78. See Stout, supra note 12 , at 1194.

79. Id. at 1193 (citing EASTERBROOK \& FISCHEL, supra note 6, at 36).

80. There are two exceptions. First, the shareholders could contractually share their residual claim. Second, shareholders may no longer be claimants when the company is insolvent. This second exception is considered below.

81. Stout, supra note 12 , at 1194 . Stout is correct in that shareholders have no right to dividends until they are declared by the board of directors. See 11 WILliam MEADE FLETCHER ET AL., FLETCHER CYCLOPEDIA OF THE LAW OF PRIVATE CORPORATIONS § 5321, at 563-66 (perm. ed., rev. vol. 2003),

82. See Merton H. Miller \& Franco Modigliani, Dividend Policy, Growth, and the Valuation of Shares, 34 J. BUs. 411, 412-15 (1961) (arguing irrelevance of dividend policy assuming perfect markets and no taxes or transaction costs). See generally RICHARD A. BREALEY ET AL., PRINCIPLES OF CORPORATE FINANCE 450-64 (9th ed. 2008).

83. Stout discounts this. According to her, "[t]hat benefit ... is indirect, and dependent on the board of directors' decisions. If the board decides to run the firm with an eye primarily to serving the interests of its executives, employees, or customers-or if they simply run it into the groundshareholders' rights to sell their shares on the open market are of little value." Stout, supra note 12, at 1194. However, this argument is more relevant to the issue of control than of residual risk. The fact remains that the shareholders bear the residual risk on all corporate actions; whether or not those corporate actions are wise or even legitimate is beside the point.

84. Historically, dividends have been subject to double taxation at the ordinary tax rates. Capital gains are taxed only once and at a lower rate. In 2003, the tax rate on dividend income was lowered, but dividends are still subject to double taxation. See Jobs and Growth Tax Relief Reconcilia- 
Thus, the contingency of dividend payments does not affect the status of shareholders as residual claimants.

Professors Blair and Stout also find support for objection to the residual claimant argument for shareholder primacy in the empirical research of Professor Lynn Lopucki. ${ }^{85}$ Lopucki conducted a study of firms in bankruptcy and concluded "that no identifiable, single residual owner class exists in most reorganizing large public companies." 86 Blair and Stout interpret this to mean that shareholders are not the lone residual claimants. ${ }^{87}$

Lopucki's work does not support this conclusion. He was studying bankruptcy law, not corporate law. ${ }^{88}$ Ownership issues are complicated by insolvency and bankruptcy, even under the traditional view. Ordinarily, shareholders hold the equity interest in the company and are its owners. As a result, they are residual claimants. Upon insolvency, however, the value of the shareholders' equity interest may be zero or even negative. ${ }^{89}$ Under such circumstances, it is not clear that they can be considered (beneficial) owners. In bankruptcy (theoretically, at least), the assets are distributed among creditors, who then become the owners. ${ }^{90}$ Lopucki's study was about the difficulties encountered in the administration of bankruptcy, before any final resolution. Because shareholders are no longer equitable owners, someone is needed to take their place controlling the business. The residual claimant, whoever it may be at that point, would be a logical substitute. Lopucki found that it can be very difficult to find a perfect substitute for shareholders in bankruptcy. ${ }^{91}$

Lopucki's study does not conclude that there is no sole residual claimant outside of bankruptcy. He merely found that, in bankruptcy, the residual claim often is shared such that there is no single residual claimant. ${ }^{92}$ However, there could be a lone residual claimant, even in bankruptcy. Indeed, his study found that in up to thirty-eight percent of

tion Act of 2003, Pub. L. No. 108-27, § 302, 117 Stat. 752, 760-64 (codified as amended in scattered sections of 26 U.S.C.).

85. See, e.g., Margaret M. Blair \& Lynn A. Stout, Specific Investment: Explaining Anomalies in Corporate Law, 31 J. CORP. L. 719, 728 (2006) ("[T]he law ... does not treat the shareholders of a corporation that is not in bankruptcy as the corporation's sole 'residual claimants." ). "Nor is it clear shareholders enjoy this status even when the firm is in bankruptcy." Id. at $728 \mathrm{n} .23$.

86. Lynn M. Lopucki, The Myth of the Residual Owner: An Empirical Study, 82 WASH. U. L.Q. 1341,1343 (2004).

87. Blair \& Stout, supra note 85 , at 728 \& n.23.

88. Lopucki, supra note 86 , at 1341.

89. Because shareholders enjoy limited liability, a negative equity interest is effectively equal to zero.

90. Cf. infra note 181 and accompanying text.

91. Lopucki, supra note 86 , at 1343 ("[T]heories depending upon the existence of a single residual owner are unworkable. The problem is not merely that single residual owners are difficult to identify. The problem is that they rarely exist.").

92. Id. at 1361 ("In at least $62 \%$ of large public company reorganizations, no identifiable single residual owner exists. Instead, two or more groups with conflicting interests with respect to the firm's investment policy share the marginal dollar of gain or loss."). 
the cases, there may have been a single residual claimant..33 Whatever implications Lopucki's work may have for shareholders' status during insolvency and bankruptcy, it does not challenge shareholder ownership outside of bankruptcy. It is perfectly consistent with Lopucki's findings that shareholders begin with the residual claim on assets but can trade it away by contract and lose it in bankruptcy. All that this means is that the shareholder's interest in the corporation is alienable-as is most property.

In fairness, there is a legitimate objection to the residual claimant argument: corporate statutes nowhere specifically provide that shareholders are residual claimants. What they tend to provide is that shareholders have the right to the net assets upon dissolution. ${ }^{94}$ However, dissolution may never occur. If the shareholders' claim is limited to a liquidation right, then it is essentially meaningless. ${ }^{95}$ This is because the directors could distribute corporate assets among the various constituents throughout the corporation's life, leaving little or nothing for shareholders upon dissolution. Thus, it can be argued that shareholders do not have any meaningful claim to the company's profits. ${ }^{96}$ However, a residual claim is much more than a liquidation right. It is the right to the remainder after all fixed claims are paid. It is not a one-time right; rather, it is a perpetual claim upon the net assets. The lack of a statutory basis for a residual claim on the part of shareholders presents a problem for contractarian theory. It does not present a similar problem for the traditional view because a residual claim flows implicitly and necessarily from ownership, rather than the other way around.

However, if shareholders are residual claimants, then they become virtually indistinguishable from owners-at least as far as other stakeholders are concerned. A perpetual claim on the net assets would prevent the directors from doing as they please: they could not distribute corporate assets to other stakeholders without infringing the rights of shareholders. At all times, directors must either distribute the net assets to shareholders in the form of dividends, or reinvest them for the benefit

93. See id. at $1360-61$. In fairness, Lopucki qualifies this finding as follows:

[T] he study's methods provide a very conservative estimate of the number of investor priority levels whose interests conflict with those of the firm.... [C]reditors [who] recovered the full amounts owing them ... [we]re not classified as residual owners....

The study's methods treat these creditors as having had no conflict with shareholders as to the firm's investment policy, even though most probably did.... As a result, this study's finding of single residual owners in $38 \%$ of reorganizing firms probably overestimates substantially. Id. at 1361 .

94. See, e.g., DEl. CODE ANN. tit. 8, § 281(a)-(b) (2001); MODEL Bus. CORP. ACT $\S 6.01(\mathrm{~b})(2)$ (2008).

95. Cf. Stout, supra note 12, at 1193 ("When the firm is not in bankruptcy, it is grossly misleading to suggest that the firm's shareholders are somehow entitled to ... everything left over after the firm's explicit contractual obligations have been met.").

96. Cf. Pyle v. Gallaher, 75 A. 373, 375 (Del. 1908) (noting that defendant's assertion "that a shareholder in a corporation has no property interest in the profits of the business carried on by the corporation until a dividend has been declared out of such profits" is "substantially correct" (internal quotation marks omitted)). 
of shareholders. ${ }^{97}$ Thus, admitting that shareholders are residual claimants presents a problem for communitarians, even if shareholder ownership is denied.

\section{What About Options Theory?}

Another theory that could call into question the shareholder's ownership of the corporation is the options theory of Professors Black and Scholes. ${ }^{98}$ Based on options theory, Professors Blair and Stout argue as follows:

From the standpoint of the financial claims and risk being borne by the two parties .... [i]t is equally sensible to describe either the stockholder or the institutional bondholder as the firm's true "owner", with the other party holding some sort of contingent claim. Options theory destroys any notion that shareholders can be uniquely described, in economic terms at least, as "owners" of corporations. ${ }^{99}$

Essentially, the claim is that, because equity and debt interests are economically equivalent, shareholders cannot be considered the owners of the corporation.

As a preliminary matter, it is worth noting that an expansive interpretation of options theory would undermine the concept of ownership altogether. To the extent that options theory suggests that

[o]nce a firm has issued debt ... it makes just as much sense to say that the debtholders "own" ... the corporation[] ... but have sold a call option to the shareholder, as it does to say that the shareholder "owns" ... the corporation[] ... but has bought a put option from the debtholders, ${ }^{100}$

it arguably also suggests that

[o]nce a [person] has [borrowed money] ... it makes just as much sense to say that the [lenders] "own" the [borrower's assets] but have sold a call option to the [borrower], as it does to say that the [borrower] "owns" the [assets] but has bought a put option from the [lenders]. ${ }^{101}$

97. Of course, reinvestment would mean entering into contracts with other stakeholders. Although this might seem like a distribution, it is not. It is an exchange, which is entirely different.

98. See generally Fischer Black \& Myron Scholes, The Pricing of Options and Corporate Liabilities, 81 J. POL. ECON. 637 (1973).

99. Margaret M. Blair \& Lynn A. Stout, Director Accountability and the Mediating Role of the Corporate Board, 79 WASH. U. L.Q. 403, 412-13 (2001).

100. Stout, supra note 12 , at 1192 .

101. Id. Corporate debt is different than personal debt in that shareholders have limited liability for corporate debt. However, it is not clear that this makes a difference. Setting aside special protections in bankruptcy law, individual debtors are in the same situation as corporate debtors: they must either pay their debts or relinquish their assets, which are sold to satisfy those debts. In theory, individual debtors face unlimited liability. However, in practice, bankruptcy can provide an individual debtor with a fresh start. 
Because nearly everyone takes on at least some debt, no one could be said to own anything. Thus, to embrace this interpretation of options theory is to deny the concept of ownership. For some scholars, this may not be a problem. However, for many scholars and most others, it would be deeply problematic.

The exact claim made by Black and Scholes was technical and limited: "Under [certain simplifying assumptions], it is clear that the stockholders have the equivalent of an option on their company's assets. In effect, the bond holders own the company's assets, but they have given options to the stockholders to buy the assets back." ${ }^{102}$ However, the simplifying assumptions adopted by Black and Scholes are unrealistic. Once the assumptions are relaxed to conform to reality, the picture becomes very different. Stock no longer resembles a simple option on the corporation's assets, but rather a very complicated series of options transactions. ${ }^{103}$ At this point, the analogy falls apart. In the real world, it is not fair to say that stock resembles an option on the assets. At most, one can say only that theoretically it may be possible to create a series of options transactions that would approximate the economic interest of stock. This claim is not nearly as persuasive. While it may provide many interesting insights into the nature of the various interests in a corporation, it does not support the claim that shareholders do not own the corporation.

It is important to remember that options theory is a financial theory, not a legal theory. It focuses on the economic interests of security holders and neglects their other interests in the corporation. But these other interests, especially control rights, are valuable and cannot be ignored. As a legal or practical matter, it makes no sense to say that "the bond holders own the company's assets" 104 merely because options theory suggests that their economic interests are, in some respects, similar to those of shareholders. In fact, options theory does not establish equivalency between equity and debt interests; it merely establishes a point of similarity. Any argument to the contrary pushes options theory beyond its limits. Black and Scholes sought to determine the price of various securities based on the prices of other securities. ${ }^{105}$ For this purpose, options theory may be useful. However, the theory is not capable of determining the legal rights of the various security holders.

Professors Mitu Gulati, William Klein, and Eric Zolt develop options theory in a more complex and comprehensive manner. ${ }^{106}$ They con-

102. Black \& Scholes, supra note 98 , at $649-50$.

103. See id. at 650-52. Even Black and Scholes admit that "these more complicated options cannot be handled by using the valuation formula [set forth in the article]... . [T] he formula cannot be used, even as an approximation, to give the value of an option on an option." Id. at 652 . However, they did maintain hope "that an analysis in the same spirit ... would allow at least a numerical solution to the valuation of certain more complicated options." Id.

104. Id. at 649 .

105. Id. at $640-44$.

106. See Gulati et al., supra note 26 , at 908-18. 
struct an intricate model that "invites attention to the question of how to allocate control among the individual participants." 107 However, in doing so, they do not purport to describe existing corporate law on the issue of ownership. To the contrary, they readily acknowledge that "present-day U.S. corporate law.... conceives that equity is the owner and that the single duty of the firm and its agents is to maximize shareholder wealth." 108 To be fair, they do "attempt to demonstrate how the concept of ownership loses much of its usefulness and why there is no natural allocation of control to equity investors" when "a different perspective on joint economic activity" is employed. ${ }^{109}$ Ultimately, however, "[their] point is that a different perspective - a nonhierarchical, nonfirm onecan add new insights." 110 In other words, they do not claim to present a descriptively accurate account of existing law, but rather a model for how the corporation can, and perhaps should, be viewed.

\section{E. What About the Nexus-of-Contracts Theory?}

The greatest challenge to the traditional view comes not from any legal argument, but from a competing theory of the firm. As we have seen, specific legal arguments fall short of disproving shareholder ownership. Where those arguments fail, however, an entirely new perspective may be more successful. The law and economics movement's nexus-ofcontracts theory ${ }^{111}$ paints a picture of the corporation that is both coherent and plausible, and thus presents a viable alternative to the traditional view.

The contractarian theory has managed to capture the attention of most contemporary academics. This is not surprising. It is a powerful tool for analyzing corporations and corporate law. It is extremely insightful, highlighting aspects of corporate law that otherwise might be overlooked or underappreciated by traditional theorists, including the advantages of enabling laws over mandatory ones, the importance of appropriate default rules coupled with flexibility, and the market for corporate control. It is also appealing because it emphasizes neutral principles-efficiency and wealth maximization. ${ }^{112}$ Even a traditionalist would have to admit that the nexus-of-contracts theory has made many valuable contributions to corporate law.

However, the relevant issue for present purposes is descriptive accuracy. A theory may be helpful in many respects without being

107. Id. at 916 .

108. Id. at 907 .

109. Id. at 894 .

110. Id. at 945 .

111. See supra note 6 and accompanying text.

112. Not everyone agrees that these are neutral principles. See, e.g., DAVID W. BARNES \& LYNN A. STOUT, CASES AND MATERIALS ON LAW AND ECONOMICS 17 (1992). 
technically correct in every particular. ${ }^{113}$ Both the traditional view and the nexus-of-contracts theory are coherent and plausible, but they are inconsistent with each other on the issue of shareholder ownership and cannot both be correct. ${ }^{114}$ In this Section, I try to point out some of the descriptive limits of contractarian theory.

As an initial matter, the concept "nexus of contracts" is quite vague. One dictionary defines nexus as "[a] bond or link; a means of conne[ct]ion between things or parts."115 Another defines the term as "center" or "focus."116 Under these definitions, the phrase nexus of contracts could describe markets as well as firms. In fact, some contractarians would argue that there are no differences between markets and firms. ${ }^{117}$ This has led Professor Melvin Eisenberg to conclude that "at bottom the nexus-of-contracts conception is not a theory of the firm: [i]t is a theory of why there are no firms." 118 However, many contractarians do appreciate the difference between markets and firms. ${ }^{119}$ Thus, I would argue only that, because the concept of a nexus of contracts can encompass both markets and firms, it risks simplifying the firm and overlooking important aspects of the corporation.

More importantly, although it may be technically accurate to describe a corporation as a nexus of contracts, it is entirely inadequate. As a constitutive matter, there is more to a corporation than just contracts. For example, there is law. There is also hierarchical structure. ${ }^{120}$ Argua-

113. $C$ f. Stephen M. Baingridge, The New Corporate Governance IN TheORy and PRACTICE 2-3 (2008).

[A] model is properly judged by its predictive power with respect to the phenomena it purports to explain, not by whether it is a valid description of an objective reality. As such, "the relevant question to ask about the 'assumptions' of a theory is not whether they are descriptively 'realistic,' for they never are, but whether they are sufficiently good approximations for the purpose at hand."

Id. (citation omitted).

114. But see infra notes $137-38$ and accompanying text.

115. X THE OXFORD ENGLISH DiCTIONARY 382 (2d ed. 1989).

116. MERRIAM-WEBSTER's COLLEGIATE DICTIONARY 783 (10th ed. 2003) (quoting the third definition provided).

117. See, e.g., Armen A. Alchian \& Harold Demsetz, Production, Information Costs, and Economic Organization, 62 AM. ECON. REV. 777, 777 (1972) ("The firm . . has no power ... any different in the slightest degree from ordinary market contracting.... To speak of managing ... is a deceptive way of noting that the employer continually is involved in renegotiation of contracts on terms that must be acceptable to both parties."); Michael C. Jensen \& William H. Meckling, Theory of the Firm: Managerial Behavior, Agency Costs and Ownership Structure, 3 J. FIN. ECON. 305, 311 (1976) ("Viewed this way, it makes little or no sense to try to distinguish those things which are 'inside' the firm (or any other organization) from those things that are 'outside' of it. There is in a very real sense only a multitude of complex relationships (i.e., contracts) ....").

118. Melvin A. Eisenberg, The Conception That the Corporation Is a Nexus of Contracts, and the Dual Nature of the Firm, 24 J. CORP. L. 819, 832 (1999).

119. See, e.g., Bainbridge, supra note 20, at 554-59; R.H. Coase, The Nature of the Firm, 4 ECONOMICA (N.S.) 386 (1937).

120. See Bainbridge, supra note 20 , at 555 ("[T] he defining characteristic of a firm is the existence of a central decisionmaker vested with the power of fiat."); Eisenberg, supra note 118, at 829 ("[T]he corporation has a dual nature... [It] can be described and understood either as a set of reciprocal arrangements or as a bureaucratic hierarchical organization."). 
bly, there are noncontractual relationships as well. ${ }^{121}$ Thus, it is descriptively wrong to say that the corporation is reducible to contracts.

Nevertheless, contractarians insist that the claim is essentially correct. For example, they would argue that their definition of "contract" is broad enough to include the relationships and hierarchy found in a corporation. ${ }^{122}$ If so, one may reasonably question the appropriateness of the term "contract." 123 In any event, law is a different matter. Here, contractarians argue that corporate law is irrelevant because it is largely a matter of default rules, from which the parties may depart if they choose. ${ }^{124}$ If corporate law is not binding, then it seems reasonable to say that it resembles contract rather than law. However, corporate law is not so simple. Some of its provisions are mandatory; this fact can be trivialized, but not denied. ${ }^{125}$ Moreover, non-mandatory rules come in different forms. Some are fairly described as default rules. Director control over the business and affairs of the corporation may be one example. ${ }^{126}$ However, others are enabling laws. An example would be a merger statute. ${ }^{127}$ Such a law simultaneously authorizes a type of transaction that otherwise would not be legal and sets forth mandatory rules for its accomplishment. Although it facilitates contract, an enabling law itself cannot be characterized as contractual. In short, there is more to the corporation than just contract, however broadly defined.

A contractarian might reject this argument by insisting that the benefits of incorporation can be recreated entirely by contract, without the assistance of corporate law. ${ }^{128}$ However, it is difficult to maintain that a

121. The significance of mere relationships is debatable. Communitarians would consider these relationships to be more significant than would traditionalists or contractarians. See infra Section II.F.

122. See STEPHEN M. BAINBRIDGE, CoRPORATION LAW AND ECONOMICs 28 (2002) ("As used by contractarians... the term [contract] is not limited to those relationships that constitute legal contracts.").

123. See Eisenberg, supra note 118 , at $822-23$ ("[W]hy is the term contracts, rather than the term reciprocal arrangements, used in the nexus-of-contracts conception? ... [B]ecause it carries connotations that nexus-of-contracts theorists find normatively or strategically appealing.").

124. See, e.g., Bernard S. Black, Is Corporate Law Trivial?: A Political and Economic Analysis, 84 Nw. U. L. REV. 542, 543 (1990); Roberta Romano, Answering the Wrong Question: The Tenuous Case for Mandatory Corporate Laws, 89 COLUM. L. REV. 1599, 1599 (1989).

125. According to Bainbridge, "most contractarians probably regard the normative story as being the more important .... As such, we cheerfully concede the existence of mandatory rules, while deploring that unfortunate fact." BAINBRIDGE, supra note 122, at 32; see also EASTERBROOK \& FISCHEL, supra note 6, at 3 ("Any theory of corporate law must account for the mandatory as well as the enabling features....").

126. See DEL. CODE ANN. tit. 8, §141(a) (2001) ("The business and affairs of every corporation ... shall be managed by or under the direction of a board of directors, except as may be otherwise provided ... in its certificate of incorporation."). Or perhaps not. Cf. 2 MODEL BuS. CORP. ACT ANN. $\$ 8.01$ (b) cmt., at 8-4-8-5 (2009) ("If a corporation does not have a shareholders agreement that satisfies the requirements of section 7.32, or if it is a public corporation, it must adopt the traditional board of directors as its governing body."). But if not, then it establishes that there are, in fact, mandatory rules.

127. See, e.g., DEL. CODE ANN. tit. 8, $\$ 251$.

128. See EASTERBROOK \& FiSCHEL, supra note 6, at 34-35; William W. Bratton, Jr., The "Nexus of Contracts" Corporation: A Critical Appraisal, 74 CoRNELl L. REV. 407, $444-45$ (1989); cf. Paul G. Mahoney, Contract or Concession? An Essay on the History of Corporate Law, 34 GA. L. REV. 873, 
corporation can be perfectly replicated by contract. At the very least, it would be impossible to create limited liability ${ }^{129}$ vis-à-vis third-party tort claimants: tort victims cannot-and almost certainly would not-grant shareholders limited liability in advance..$^{130}$ Other benefits of incorporation also might be recreated by contract more easily in theory than in practice. $^{131}$ But even if they could be replicated by contract, the fact remains that existing corporations are not merely creatures of contract.

In addition, as a theory of the firm, the nexus-of-contracts model proves too much. Although its proponents generally focus on large public corporations, the theory logically applies equally well to other forms of business. ${ }^{132}$ Smaller corporations, closely held corporations, limited liability companies, partnerships, even sole proprietorships-all of them fall within the description, nexus of contracts. In each case, various stakeholders invest assets in the business with the expectation of some return. Equity holders - whether shareholders, members, partners, or sole proprietors - invest capital in exchange for the residual return; debt holders invest capital in exchange for a fixed return; employees invest labor in exchange for fixed salaries; customers invest revenue in exchange for products or services. In short, if contractarians are correct, then every business must be nothing more than a nexus of contracts. As a result, the theory which seemed so plausible with respect to public corporations becomes much less convincing.

892-93 (2000) ("The benefits of treating a business as something separate from its owners are so obvious and overwhelming that it has never required substantial governmental assistance to achieve.").

129. The issue of limited liability deserves additional attention. At first glance, it may seem to cause problems for the traditional view. After all, owners generally are held liable for the obligations of their businesses and others are not. This is true for sole proprietorships and partnerships, so it might seem that shareholders should not be considered owners. In fact, however, shareholders would be held liable but for the special protection of the doctrine of limited liability. Under certain circumstances, courts in equity will "pierce the corporate veil" to hold shareholders liable for the obligations of the corporation. GEVURTZ, supra note $44, \S 1.5$, at $69-111$. This makes sense only if shareholders are owners. If they truly were just like other stakeholders, they should not face personal liability any more than others do. Cf. Gulati et al., supra note 26 , at 930 ("[I]t is interesting and surprising that no one seems to have considered the possibility of applying the arguments for shareholder personal liability to other participants.... [ [If] there are no clear boundaries and no owners ... the scope of potentially liable persons might be virtually infinite."). Thus, the existence of the exceptional doctrines of limited liability and piercing the corporate veil actually provide support for the claim of shareholder ownership.

130. See Lynda J. Oswald, Shareholders v. Stakeholders: Evaluating Corporate Constituency Statutes Under the Takings Clause, 24 J. CORP. L. 1, 18 (1998) ("Even if the owners of the firm were able to overcome the transaction costs of negotiating with their contract creditors one-on-one for limited liability, it would be impossible for them to so negotiate with future tort creditors." (footnote omitted)). Contractarians may find justifying the rule of limited liability quite easy, see BAINBRIDGE, supra note 122 , at 138-45, but that does not change the fact that the rule is not contractual in any meaningful sense.

131. At the very least, investors are more likely to be comfortable with the corporate form than with a purely contractual enterprise that they must trust has replicated a corporation adequately.

132. See Jensen \& Meckling, supra note 117, at 310-11 ("[M]ost organizations are simply legal fictions which serve as a nexus for a set of contracting relationships among individuals.... The private corporation or firm is simply one form ...." (emphasis omitted)). 
Contractarians believe that, because it is a nexus of contracts, the corporation is not a thing capable of being owned. ${ }^{133}$ This claim was considered in a previous Section and found to be unpersuasive as a standalone argument. ${ }^{134}$ Its reliance on the nexus-of-contracts theory only complicates matters: if a nexus of contracts is not capable of being owned, and every business is a nexus of contracts, then no business is capable of being owned-not even a sole proprietorship. This is clearly wrong. Thus, we may conclude that the contractarian claim about corporate ownership is wrong (or at least unfounded).

Professor Bainbridge's director primacy theory adds a slight wrinkle to the nexus-of-contracts theory. He argues that a corporation has, rather than is, a nexus of contracts, and that the nexus is the board of directors. ${ }^{135}$ This is because the board of directors has the power to manage the corporation and is the group that interacts with all other groups. Thus, Bainbridge puts the board of directors in the center of his corporate diagram: $:^{136}$

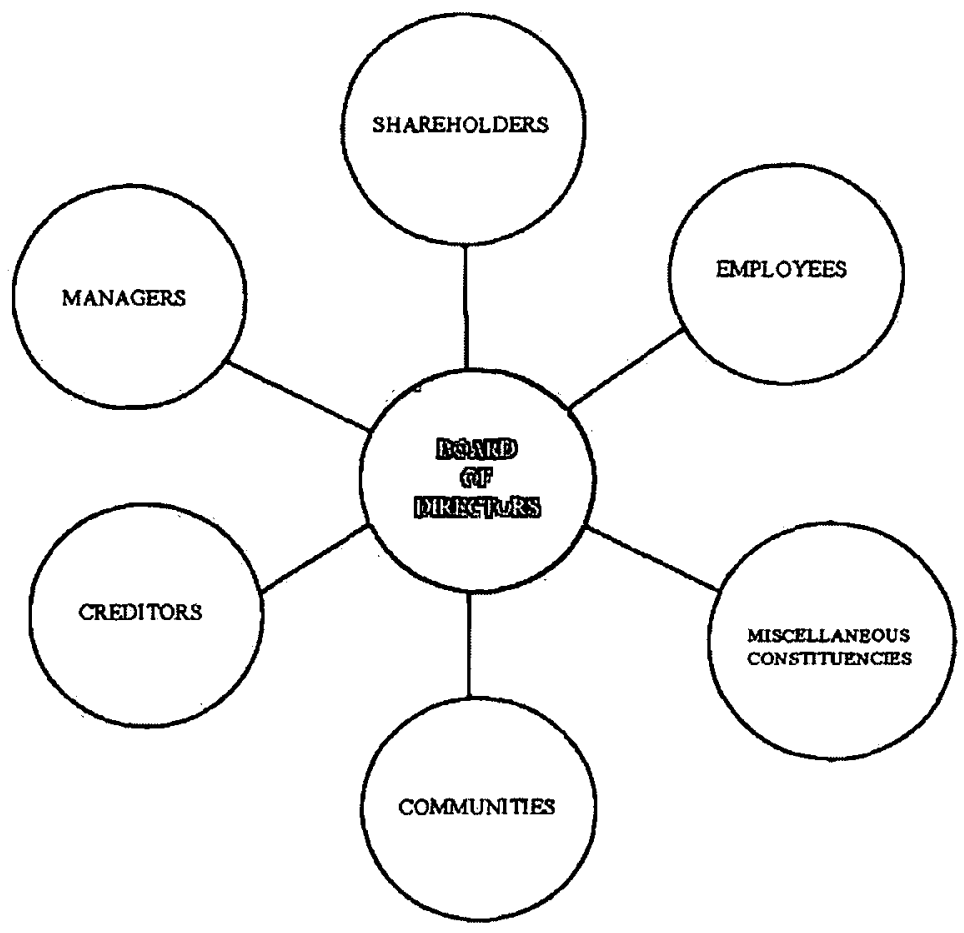

133. See supra Part II.A.

134. See supra Part II.A.

135. See Bainbridge, supra note 20, at 554-60.

136. See id. at 560 fig.3. 
This diagram makes his claim seem obvious. However, the shareholders' right to elect directors and the directors' fiduciary duties to manage the corporation in the interests of shareholders suggest that it is misleading to consider the board of directors to be the corporate nexus. The traditional view holds that the shareholders are the focus of the corporation.

The problem with Bainbridge's diagram is that it lumps shareholders together with other stakeholders. A more precise corporate diagram would reflect the fact that shareholders elect directors to contract with other stakeholders on their behalf:



In this revised diagram, directors may remain at the center, but they are certainly not the focus. Rather, they act as the bridge between shareholders and other stakeholders. This diagram, which better reflects corporate law, points to the shareholder as the true focus of the corporation.

Contractarians are unlikely to be impressed by the discussion in this Section, or any earlier Section of this Article. According to Bainbridge, "the debate [over the contractual nature of the firm] has been fully 
played out. Contractarians and noncontractarians no longer have much of interest to say to one another; indeed, they barely speak the same language." ${ }^{137}$ I tend to agree with his assessment. However, I believe that the difference between the two theories is largely a matter of semantics. Under the traditional view, the corporation is a separate entity owned by the shareholders that transacts business with others. Under the nexus-ofcontracts theory, by contrast, the corporation is the entire business enterprise, including all stakeholder interests. Clearly, the two theories are not discussing the same concept. Thus, both theories can be correct on their own terms: shareholders own what the traditional view considers a corporation, but not what the contractarian theory considers a corporation. ${ }^{138}$ In fact, the two theories do not disagree about ownership of any particular component of the business: they both acknowledge that shareholders have the rights provided by law and those set forth in the charter-including the right to vote for directors, the residual claim on assets, and the right to the loyalty of directors in pursuing shareholder wealth and that shareholders have no claim to the inputs of other stakeholders, such as the employees' labor. Thus, the traditionalist and the contractarian are not exactly disagreeing on the issue of shareholder ownership; they are speaking past each other.

Nevertheless, it is important to insist upon the traditional view for at least two reasons. First, the legal definition of the term corporation is consistent with the traditional view. Thus, even though contractarian theory may be correct when properly understood, its conclusions cannot be imported directly into other conversations without translation. Shareholders may not own what contractarians call a corporation, but they do own what nearly everyone else-including, as I hope to show in Part III, the law - calls a corporation. Second, the conclusion that shareholders do not own the corporation can be problematic. Although contractarians do a commendable job in defending the norm of shareholder wealth maximization with arguments of economic efficiency, their conclusions are not inexorable. As we shall see, if shareholders do not own the corporation, then the norm of shareholder wealth maximization is subject to challenge. Thus, the stability of corporate law and the very purpose of corporations may depend upon shareholder ownership.

\section{F. What About Stakeholders?}

Many corporate law scholars are more concerned about the rights of other stakeholders than those of shareholders. Their problem with the traditional view is that it singles out the shareholder as the sole concern of the corporation. In their view, the corporation is an institution that should benefit all of society. Therefore, they reject shareholder wealth

137. See BAINBRIDGE, supra note 122 , at 31 .

138. Contra supra text accompanying note 114. 
maximization as the goal of the corporation. As I have elsewhere, I refer to these scholars collectively as social responsibility theorists. ${ }^{139}$

Historically, social responsibility theorists have accepted the basic framework of the traditional view and merely sought to impose a level of corporate social responsibility on directors. ${ }^{140}$ More recently, however, they have come to question claims of shareholder ownership. Contemporary social responsibility theorists are often referred to as communitarians. ${ }^{141}$ "Communitarians generally accept [the contractarian] description of the firm. However, they do not accept the structure of shareholder primacy that contractarians tend to build on this foundation." 142 They agree with contractarians that shareholders do not own the corporation. However, they believe that the contractarian focus on explicit contracts ignores important implicit contracts and relational interests. Thus, communitarians would characterize the corporation not as a nexus of contracts, but as a community, or a nexus of relationships. ${ }^{143}$ This leads them to a very different conclusion about the purpose of the corporation: "the corporation must be run consciously in the interests of society as a whole."144

Given the premise that the corporation is an unownable nexus, the communitarian's conclusions are at least as plausible as the contractarian's. If shareholders do not own the corporation, it is not obvious why the corporation should be run solely in their interests. Thus, the communitarian theory of the firm cannot be dismissed easily.

Because it shares the same basic premises, communitarian theory is subject to the same types of criticism as contractarian theory. ${ }^{145}$ For example, the concept of a nexus of relationships is even more vague than a nexus of contracts. Almost any human endeavor could be described as a nexus of relationships. In addition, a corporation is more than just a nexus of relationships. As previously discussed, it also involves law. Some of these laws protect stakeholders, ${ }^{146}$ while others protect shareholders. ${ }^{147}$ All of them should be respected. Moreover, not all relationships are of equal significance, legally or otherwise. Thus, to say that relationships are involved is not terribly helpful. Finally, like nexus-ofcontracts theory, it simply proves too much. If a nexus of relationships is

139. See Velasco, supra note 2, at 451-52.

140. See, e.g., E. Merrick Dodd, Jr., For Whom Are Corporate Managers Trustees?, 45 HARV. L. REV. 1145, 1155-56 (1932).

141. See Peter C. Kostant, Team Production and the Progressive Corporate Law Agenda, 35 U.C.

DAVIS L. REV. 667, 674-76 (2002). See generally sources cited supra note 9.

142. Velasco, supra note 2 , at 456.

143. See, e.g., Millon, supra note 5 , at 10.

144. Velasco, supra note 2 , at 456 (citing Greenfield, supra note 9, at 89 ).

145. See supra Part II.E.

146. Morey W. McDaniel, Stockholders and Stakeholders, 21 STETSON L. REV. 121, 146-47 (1991).

147. William S. Hochstetler \& Mark D. Svejda, Statutory Needs of Close Corporations-An Empirical Study: Special Close Corporation Legislation or Flexible General Corporation Law?, 10 J. CORP. L. 849, 1006-10 (1985). 
beyond ownership, then it is not merely business organizations that are at risk, but the concept of property itself. There are always relationships surrounding property as well as third parties who may be affected greatly by the decisions of property owners, but neither fact automatically conveys ownership interests or property rights under the law. Thus, while the nexus-of-relationships concept can be a helpful framework for discovering different dimensions of the corporation, especially when it supplements nexus-of-contracts theory, it is not well suited to legal analysis.

On the issue of ownership, communitarians do not stand on solid ground. As I have sought to establish throughout this Part, legal arguments fail to establish that shareholders are not owners. It would be even more difficult to establish that other stakeholders are co-owners: ${ }^{148}$ they simply do not have any of the incidents of ownership, nor any legal claim to them. At most, it could only be argued that they deserve to be considered co-owners - and that would be a very debatable position.

Ultimately, the central issue for social responsibility theorists is not shareholder ownership, but stakeholder rights. However, there are many ways that the law can protect the latter without disrupting the former. For example, employees can be protected by minimum wage, collective bargaining, and workplace safety legislation. Lenders can be protected by security interests and fraudulent transfer laws. Consumers can be protected by implied warranties, safety standards, and products liability. Communities can be protected by land use regulation, taxation, and other general laws. In fact, current law provides protections along each of these lines. If these laws are insufficient, they can be enhanced or supplemented with additional protections. Thus, a denial of shareholder ownership would be an extreme and unnecessary solution to the problems identified by social responsibility theorists.

Social responsibility theorists do not always emphasize ownership issues. Often, they argue that the directors owe their fiduciary duties to the corporation as a separate legal entity rather than to the shareholders. ${ }^{149}$ This argument has some merit, but it does not accomplish what its proponents would like it to.

One reason the argument fails is because it does, in fact, depend upon denial of shareholder ownership. If the corporation is to be treated as a separate entity, then it makes sense to have directors pursue the interests of the corporation rather than those of its shareholders. However, the corporation is distinct not only from its shareholders, but also from its other stakeholders. Thus, the corporation should not seek to balance the interests of the various stakeholders, ${ }^{150}$ but rather should pursue its own interests by maximizing its own wealth. In other words, it should act as a separate entity - a sole proprietorship. However, because

148. See supra note 42 and accompanying text.

149. See, e.g., Blair \& Stout, supra note 9, at 293-94; Dodd, supra note 140, at 1160-61.

150. Cf. Blair \& Stout, supra note 9, at 253. 
shareholders own that entity, the wealth generated by the corporation redounds to their benefit. ${ }^{151}$ As previously discussed, this is true regardless of whether the wealth is distributed in the form of dividends. ${ }^{152}$ In order to reach a different conclusion, social responsibility theorists must assume (at least implicitly) that shareholders are not owners and ignore their residual claim. If no one has a right to the wealth amassed by the corporation, then it would seem entirely reasonable to share it among the various participants in the corporate enterprise. But if shareholders are owners, or even merely residual claimants, then the corporate wealth belongs to them. ${ }^{153}$

Another reason the argument fails is that directors do owe their fiduciary duties to the shareholders. In fact, the most common formulation used by the courts is that directors owe their fiduciary duties to "the corporation and its shareholders." 154 The conclusion that fiduciary duties are owed to the corporation as a separate entity is entirely logical and makes sense as a matter of law. In fact, the courts have said so explicitly: "It is well settled that directors owe fiduciary duties to the corporation." 155 However, fiduciary duties are a matter of equity, which is concerned more with substance and fairness than form and technicalities. ${ }^{156}$ Thus, courts in equity recognize that fiduciary duties that are owed to the corporation redound to the benefit of shareholders and therefore allow

151. See N. Am. Catholic Educ. Programming Found., Inc. v. Gheewalla, 930 A.2d 92, 101 (Del. 2007) (describing shareholders as "the ultimate beneficiaries of the corporation's growth and increased value").

152. See supra notes $81-84$ and accompanying text.

153. See supra notes $94-97$ and accompanying text.

154. See, e.g., Unocal Corp. v. Mesa Petroleum Co., 493 A.2d 946, 954 (Del. 1985). I believe that this language suggests an equivalence between the corporation and its shareholders, which makes sense only under the traditional view. On its face, the statement is ambiguous. In context, however, it is less ambiguous:

[T]he equivalence of "corporation" and "shareholders" ... is most clearly seen in the manner in which courts and writers have used these terms, and that usage tends to show that they use them as equivalents. In Unocal, the Delaware Supreme Court, in the course of two pages, described the directors' "fundamental duty and obligation" as running first to "the corporate enterprise, which includes stockholders," later to "the corporation and its shareholders," and finally, to just "the corporation's stockholders."

A.A. Sommer, Jr., Whom Should the Corporation Serve? The Berle-Dodd Debate Revisited Sixty Years Later, 16 DEL. J. CORP. L. 33, 48-49 (1991) (citations omitted). There are other presumably equivalent formulations as well, including simply "to the corporation" and to "the corporation for the benefit of its shareholder owners." Gheewalla, 930 A.2d at 101.

Some might argue to the contrary. For example, they might point out that one of the Unocal court's formulations was "the corporate enterprise, which includes stockholders." 493 A.2d at 954. This is ambiguous in that it could mean that the corporation includes shareholders as well as other stakeholders. Whether or not that would be a reasonable interpretation of the formulation standing alone, it is not a reasonable interpretation of the formulation in the context of that opinion and the other formulations. The best interpretation is that fiduciary duties are owed not only to the corporation as a separate entity, but also to the shareholders as owners and ultimate beneficiaries.

155. Gheewalla, 930 A.2d at 101.

156. See Uni-Marts, Inc. v. Stein, Civ. A. Nos. 14713, 14893, 1996 WL 466961, at*9 (Del. Ch. Aug. $12,1996)$ ("[T]he essential fiduciary analysis component of corporation law is not formal but substantive ...."); Speiser v. Baker, 525 A.2d 1001, 1011 (Del. Ch. 1987) ("[O]ur law is the polar opposite of technical and literal when the fiduciary duties of corporate officers and directors are involved."). 
shareholders to enforce them. The courts have been explicit on this as well: "When a corporation is solvent, those duties may be enforced by its shareholders, who have standing to bring derivative actions on behalf of the corporation because they are the ultimate beneficiaries of the corporation's growth and increased value." 157 So it is difficult to maintain that directors do not, in fact, owe their fiduciary duties to the shareholders. ${ }^{158}$

At the heart of social responsibility theory lies an attempt to instill a greater sense of morality in directors and shareholders. This goal is reasonable enough - perhaps even noble. ${ }^{159}$ However, it is ultimately aspirational. "To be a meaningful concept, social responsibility must extend beyond legal requirements - and thus, by definition, cannot be legally enforceable. Social responsibility, then, is more of an exhortation than a command." 160 Even so, the concept of social responsibility cannot reasonably demand that shareholders should put the welfare of others before their own. Shareholders should be able to prosper and profit from their investments just as they should not prevent others from doing the same. In other words, shareholders should be reasonable but need not be self-sacrificing or charitable. They certainly need not surrender their rights as owners.

Social responsibility theory reminds us that there are many stakeholders that are affected by corporate decisions. However, this is equally true of all property: third parties are affected by the decisions of owners. This is not a sufficient basis for denying ownership to some or extending it to others. At most, it is a basis for regulating what owners are permitted to do with their assets.

\section{The AFFirmative CASE}

In Part II, I addressed the arguments that form the core of the contemporary critique of the traditional view. I showed that these arguments fall short of establishing that shareholders are not owners. In this Part, I evaluate additional arguments often leveled against the traditional view in order to develop an affirmative case for shareholder ownership. First, I demonstrate that the law expressly provides that shareholders own the corporation. On one important level, this should settle the question. Then I argue that shareholders in public corporations are as much owners as are the equity holders of other forms of business. Finally, I address the claim that shareholders do not consider themselves owners. I

157. Gheewalla, 930 A.2d at 101.

158. Communitarians often raise the existence of constituency statutes in support of their claim that shareholders are not the sole subject of directors' fiduciary duties. However, constituency statutes do not support their claims. As I have argued elsewhere, granting directors a limited ability to take other stakeholders' interests into consideration is not the same as extending the protections of fiduciary duties to those stakeholders. See Velasco, supra note 2, at 462-66.

159. But see Milton Friedman, A Friedman Doctrine-The Social Responsibility of Business Is to Increase Its Profits, N.Y. TIMES MAG., Sep. 13, 1970, at 32, 124-26.

160. Velasco, supra note 2, at 454 (citation omitted). 
hope to establish that the traditional view of the corporation remains a viable position.

\section{A. What Do Shareholders Own?}

There are some who maintain that the traditional view has no basis in law. For example, Martin Lipton has argued as follows:

Shareholders do not "own" corporations. They own securitiesshares of stock - which entitle them to very limited electoral rights and the right to share in the financial returns produced by the corporation's business operations. Conceiving of public shareholders as "owners" may in some instances be a helpful metaphor, but it is never an accurate description of their rights under corporate law. ${ }^{161}$

The first question to be considered, then, is the most simple: what do shareholders own? More precisely, I try to answer the question, what does the law say that shareholders own?

Of course, it is true that shareholders own shares of stock. However, this does not mean that they do not own the corporation as well. Whether or not they do depends upon what shares of stock are. Lipton's position assumes that they are merely contracts, like debt securities. If so, it makes sense to think of the shareholder simply as having certain financial and control rights against the corporation. The traditionalist, however, insists that a share of stock is akin to a deed that represents title. If so, it makes sense to say that the shareholders own the corporation. What does the law say?

Most states have adopted the Model Business Corporation Act. ${ }^{162}$ Under its provisions, the answer is strikingly simple. "Shares" are explicitly defined as "the units into which the proprietary interests in a corporation are divided."163 "Proprietary" is not defined by statute, but the dictionary meaning of the term is "[b]elonging to a proprietor or proprietors; owned or held as property; held in private ownership." 164 This is a clear statement that shareholders are indeed the legal owners of the corporation.

Unfortunately, the matter is not settled so easily. This is because the single most important state for corporate law purposes is Delaware. The Delaware General Corporation Law does not define the term stock or otherwise say what it represents. ${ }^{165}$ Thus, the Delaware General Cor-

161. Martin Lipton \& William Savitt, The Many Myths of Lucian Bebchuk, 93 VA. L. REV. 733, 754 (2007); see also Martin Lipton \& Steven A. Rosenblum, Election Contests in the Company's Proxy: An Idea Whose Time Has Not Come, 59 Bus. LAw. 67, 72-73 (2003); Stout, supra note 12, at 1191.

162. See 1 MODEL BUS. CORP. ACT ANN. ix \& nn.1-2 (2009).

163. MODEL BUS. CORP. ACT $\S 1.40(22)$ (2008); see also CAL. CORP. CODE $\$ 184$ (West 1990).

164. XII THE OXFORD ENGLISH DICTIONARY 655 (2d ed. 1989).

165. Arguably, the closest that the Delaware code comes to a definition is the provision that each class of stock shall have such rights as are specified in the charter. See DEL. CODE ANN. tit. 8, § 151(a) (2001). This does not sound like an ownership interest; to the contrary, it sounds more like a contractual investment. One may be tempted to read this provision as if it allowed a corporation to sell 
poration Law does not provide explicitly that shareholders own the corporation. However, it does not state explicitly that they do not, either. The Delaware statute is simply silent on the issue of ownership. ${ }^{166}$ Thus, we must turn to other sources of law to determine what shareholders own.

Admittedly, it is difficult to find very much case law directly addressing the issue of ownership. However, there is a great deal of case law that implicitly reaffirms the traditional view. For example, as discussed earlier, Delaware courts generally insist that the directors of a corporation owe their fiduciary duties "to the corporation and its shareholders." 167 Unfortunately, most of the courts' statements on fiduciary duties are ambiguous. While they do support the traditional view, they also can be interpreted consistently with other theories.

However, a few lines of cases are more helpful. For example, the Delaware Supreme Court has permitted directors to consider the interests of other stakeholders, but only if "there are rationally related benefits accruing to the stockholders."168 This undermines communitarian theory because it makes clear that, in the final analysis, shareholders must be the primary concern of the directors. Another example can be found in cases involving director interference with shareholder voting. In such cases, the courts have required compelling justification on the grounds that "[t]he shareholder franchise is the ideological underpinning upon which the legitimacy of directorial power rests." 169 Such a statement makes perfect sense under the traditional view: it is a reminder that

shareholders securities with whatever rights it may choose to give them. However, this would be inappropriate. The Model Business Corporation Act, which already defines shares as representing ownership interests, contains a similar provision. See MODEL BUS. CORP. ACT $§ 6.01$ (a). Thus, the provision is neither a definition nor incompatible with ownership. To the contrary, it merely gives shareholders the flexibility to differentiate among themselves by establishing different classes of stock. This is preferable to requiring uniform rights, regardless of the circumstances.

166. Interestingly, section 220 of the Delaware General Corporation Law defines the term "subsidiary" as follows: "any entity directly or indirectly owned, in whole or in part, by the corporation of which the stockholder is a stockholder ... and includes, without limitation, corporations, partnerships, limited partnerships, limited liability partnerships, limited liability companies, statutory trusts and/or joint ventures." DEL. CODE ANN. tit. 8, \$220(a)(3) (Supp. 2008). This language clearly assumes that shareholders are owners because the parent corporation is said to own the subsidiary, in whole or in part. Unfortunately, the language quoted above is only a definition for purposes of section 220 , not the entire act. However, it provides support for the claim that the shareholder's ownership interest is implicit in the Delaware General Corporation Law.

167. See supra note 154 and accompanying text.

168. Revlon, Inc. v. MacAndrews \& Forbes Holdings, Inc., 506 A.2d 173, 182 (Del. 1986) (citations omitted). More specifically:

A board may have regard for various constituencies in discharging its responsibilities, provided there are rationally related benefits accruing to the stockholders. However, such concern for non-stockholder interests is inappropriate when an auction among active bidders is in progress, and the object no longer is to protect or maintain the corporate enterprise but to sell it to the highest bidder.

Id. at 182 (citation omitted).

169. Blasius Indus., Inc. v. Atlas Corp., 564 A.2d 651, 659 (Del. Ch. 1988); see also MM Cos. v. Liquid Audio, Inc., 813 A.2d 1118, 1126 (Del. 2003) (quoting Blasius, 564 A.2d at 659); Centaur Partners, IV v. Nat'l Intergroup, Inc., 582 A.2d 923, 927 (Del. 1990). 
directors have authority to run the business only because the owners have appointed them. But it undermines contractarian theory under which the only ideological underpinning is contract. Shareholder voting may be desirable as a policy matter, but is not theoretically necessary. Of course, one must be careful not to read too much into such statements. However, my point is this: the law of fiduciary duties in Delaware reflects the traditional view. It may be consistent with other theories in some respects, but the fit is much less comfortable.

There also are various cases in which the Delaware Supreme Court has referred to shareholders as owners. For example, in Unocal Corp. $v$. Mesa Petroleum Corp., the Court generally spoke of "the corporation and its shareholders." 170 However, in one instance, the court instead referred to "the corporation and its owners." 171 This formulation has been used in other cases as well. ${ }^{172}$ Again, one must be careful not to read too much into statements made in passing. However, such a slip would not be likely to occur if courts agreed that corporations were not capable of being owned.

Moreover, the Delaware Supreme Court has repeatedly grounded shareholder inspection rights on the principle of ownership. For example, in Seinfeld v. Verizon Communications, Inc., the court explained:

Delaware corporate law provides for a separation of legal control and ownership. The legal responsibility to manage the business of the corporation for the benefit of the stockholder owners is conferred on the board of directors by statute. The common law imposes fiduciary duties upon the directors of Delaware corporations to constrain their conduct when discharging that statutory responsibility.

Stockholders' rights to inspect the corporation's books and records were recognized at common law because as a matter of selfprotection, the stockholder was entitled to know how his agents were conducting the affairs of the corporation of which he or she was a part owner. The qualified inspection rights that originated at common law are now codified .... ${ }^{173}$

This type of statement is not exactly made in passing. It certainly provides support for the traditional view. Nevertheless, such statements are not exactly determinative.

However, in at least one case, the Delaware Supreme Court has explicitly recognized that shareholders are the owners of the corporation. In North American Catholic Educational Programming Foundation, Inc.

170. 493 A.2d 946, 952, 954 (Del. 1985); see also id. at 958.

171. See id. at 955 .

172. See, e.g., Armstrong v. Pomerance, 423 A.2d 174, 176-77 n.5 (Del. 1980); Ruggiero v. FuturaGene, P.L.C., 948 A.2d 1124, 1133 (Del. Ch. 2008); Grand Metro. P.L.C. v. Pillsbury Co., 558 A.2d 1049, 1055 (Del. Ch. 1988).

173. 909 A.2d 117, 119 (Del. 2006) (footnotes omitted) (internal quotation marks omitted); see also Saito v. McKesson HBOC, Inc., 806 A.2d 113, 116 (Del. 2002). 
v. Gheewalla, NACEPF, a creditor of Clearwire Holdings, Inc., sought to bring a direct action against the company's directors for breach of fiduciary duty. ${ }^{174}$ The plaintiff argued that "because, at all relevant times, Clearwire was either insolvent or in the 'zone of insolvency,' the Defendants owed fiduciary duties to NACEPF 'as a substantial creditor of Clearwire, ${ }^{175}$ and that the directors breached their fiduciary duties by "favor[ing] [the shareholders'] agenda."176 The court's holding was that "individual creditors of an insolvent corporation have no right to assert direct claims for breach of fiduciary duty against corporate directors." 177 However, in the course of its opinion, the court provided a clear account of the traditional view: "Delaware corporate law provides for a separation of control and ownership. The directors of Delaware corporations have 'the legal responsibility to manage the business of a corporation for the benefit of its shareholders [sic] owners."'178

Closer examination of the court's opinion reveals that this statement was not errant dictum. The plaintiff relied on the principle that "where a corporation is operating in the vicinity of insolvency, a board of directors is not merely the agent of the [shareholders], but owes its duty to the corporate enterprise."179 The Delaware Supreme Court responded by clarifying the nature of fiduciary duties:

It is well established that the directors owe their fiduciary obligations to the corporation and its shareholders.... Accordingly, the general rule is that directors do not owe creditors duties beyond the relevant contractual terms.

...When a solvent corporation is navigating in the zone of insolvency, the focus for Delaware directors does not change: directors must continue to discharge their fiduciary duties to the corporation and its shareholders by exercising their business judgment in the best interests of the corporation for the benefit of its shareholder owners. ${ }^{180}$

In other words, shareholders are owners and directors must run the corporation for their benefit, even when in the "zone of insolvency."

The court did permit the creditors of a corporation that actually is insolvent to pursue a breach of fiduciary duty claim in a derivative action, as opposed to a direct action. However, it did so for reasons entirely consistent with the traditional view:

174. 930 A.2d 92, 94-95 (Del. 2007). For another instance, see also Malone v. Brincat, 722 A.2d 5, 7 (Del. 1988).

175. Gheewalla, 930 A.2d at 95 .

176. Id. at 93 .

177. Id. at 103 .

178. Id. at 101 (footnote omitted) (quoting Malone, $722 \mathrm{~A} .3 \mathrm{~d}$ at 9)

179. Credit Lyonnais Bank Nederland, N.V. v. Pathe Commc'ns Corp., Civ. A. No. 12150, 1991 WL 277613, at *34 (Del. Ch. Dec. 30, 1991).

180. Gheewalla, 930 A.2d at 99-101 (internal quotation marks omitted) (footnotes omitted). 
It is well settled that directors owe fiduciary duties to the corporation. When a corporation is solvent, those duties may be enforced by its shareholders, who have standing to bring derivative actions on behalf of the corporation because they are the ultimate beneficiaries of the corporation's growth and increased value. When a corporation is insolvent, however, its creditors take the place of the shareholders as the residual beneficiaries of any increase in value.

Consequently, the creditors of an insolvent corporation have standing to maintain derivative claims against directors on behalf of the corporation for breaches of fiduciary duties. The corporation's insolvency makes the creditors the principal constituency injured by any fiduciary breaches that diminish the firm's value. Therefore, equitable considerations give creditors standing to pursue derivative claims against the directors of an insolvent corporation. Individual creditors of an insolvent corporation have the same incentive to pursue valid derivative claims on its behalf that shareholders have when the corporation is solvent.

The fact that the corporation has become insolvent does not turn [derivative] claims into direct creditor claims, it simply provides creditors with standing to assert those claims. At all times, claims of this kind belong to the corporation itself .... ${ }^{181}$

In other words, given the independent legal status of the corporation, directors technically owe their fiduciary duties to it. In reality, this duty runs to the beneficial owners, which ordinarily are the shareholders. However, when the company is insolvent, shareholders have no equity in the company and creditors effectively become the beneficial owners. This is entirely consistent with the traditional view.

Gheewalla is a recent case decided by the Delaware Supreme Court which does as much to uphold the traditional view of the corporation as reasonably can be expected of a court decision. ${ }^{182}$ It is admittedly difficult to find many cases directly on point. However, because the corporation legally is an entity that is separate and distinct from its shareholders, it is not very often that the courts have to opine on the issue of ownership directly. Thus, the lack of abundant case law support should not be surprising.

181. Id. at $101-02$ (alteration in original) (internal quotation marks omitted) (footnotes omitted).

182. The most well-known case that endorses the traditional view is probably Dodge v. Ford Motor Co., 170 N.W. 668 (Mich. 1919). Technically, that case addresses the purpose of corporations rather than ownership issues. Moreover, the discussion in that case has been criticized as mere dictum. See Lynn A. Stout, Why We Should Stop Teaching Dodge v. Ford, 3 VA. L. \& BUS. REV. 163, 168 (2008). Presumably, the same type of arguments could be leveled against Gheewalla or any similar case. However, at least in Gheewalla, shareholder ownership both is explicit and provides the rationale for the court's holding. 
In summary, the claim that shareholders own only shares of stock in corporations and not the corporations themselves seems to be descriptively inaccurate under the law. The law provides that the shareholders do indeed own the corporation. In most states, this is dictated by statute. In Delaware, it is spelled out in case law.

\section{B. Do Shareholders Resemble Owners?}

At the core of the critique of the traditional view lies an appeal to common sense: shareholders of public corporations simply do not resemble other owners, such as sole proprietors. Professor Jill E. Fisch has summarized the issue as follows: "From a practical perspective, shareholders ... do not resemble traditional owners. They are a fluid and fluctuating group of investors, many of whom hold only short-term interests, and perhaps most importantly, they do not exercise the control associated with traditional property rights." ${ }^{183}$ Essentially, the argument is that because shareholders do not resemble owners, it does not make sense to speak of them as owners or to afford them the rights associated with ownership.

On its face, the argument seems reasonable. However, the response of the traditionalist is both simple and intuitive: shareholders of public corporations do resemble owners. This is because public corporations are simply larger versions of small businesses. The only difference between the two is one of scale, in terms of size and the number of owners. Such factors may affect the appearance of the equity interest, but they do not alter its fundamental nature.

No one denies that a sole proprietor owns the sole proprietorshipother than, perhaps, to say that a sole proprietor is the sole proprietor-

183. Jill E. Fisch, Measuring Efficiency in Corporate Law: The Role of Shareholder Primacy, $31 \mathrm{~J}$. CORP. L. 637, 649 (2006). The issue has remained substantially the same since identified long ago by Professors Berle and Means:

[·] Most fundamental of all, the position of ownership has changed from that of an active to that of a passive agent....

[.] The spiritual values that formerly went with ownership have been separated from it...

[.] The value of an individual's wealth ... depend[s] on forces entirely outside himself and his own efforts....

[.] The value of the individual's wealth not only fluctuates constantly ... but it is subject to a constant appraisal....

[.] Individual wealth has become extremely liquid through the organized markets....

[.] Wealth is less and less in a form which can be employed directly by its owner....

[.] Finally, in the corporate system, the "owner" of industrial wealth is left with a mere symbol of ownership while the power, the responsibility and the substance which have been an integral part of ownership in the past are being transferred to a separate group in whose hands lies control.

BERLE \& MEANS, supra note 4, at 66-68. 
ship. ${ }^{184}$ Nevertheless, by the time a company grows into a public corporation with thousands of shareholders, many feel comfortable denying that its shareholders are owners. Apparently, at some point in the life of a business, the nature of the equity interest changes dramatically and loses its claim to ownership. However, it is never clear what that point would be, or why. ${ }^{185}$

If a sole proprietor were to take on one or a few partners, together they would own the business. This is clear even from the definition of partnership, which includes the concept of ownership: "A partnership is an association of two or more persons to carry on as co-owners a business for profit." ${ }^{186}$ Joint ownership is simply not a problem, and it does not matter whether there are only a few partners or many. Thus, partnership cannot be the point at which the equity holders lose their ownership interest.

Incorporation is the first point at which it can be argued that the nature of the equity interest changes. When shareholders contribute cash or other assets in exchange for shares of stock, the corporation becomes the owner of the assets contributed. Thus, one could argue that shareholders voluntarily relinquish their ownership claim. However, that would be inaccurate. As we have seen, shares represent an ownership interest in the firm. Thus, shareholders give up their ownership of the business assets but receive ownership of the entity that holds those assets. The ownership claim is not relinquished, but transformed.

Moreover, experience and common sense suggest that incorporation itself does not cause the loss of the ownership interest. If a sole proprietor or partners were to incorporate their businesses, few would care to deny that they remain owners. Shareholders in closely held corporations resemble owners as much as partners do. Thus, we must look elsewhere to explain the loss of the ownership claim.

An initial public offering is another point at which it might be argued that the nature of the equity interest in a business changes. It seems plausible that the process of going public would cause a fundamental change because of the dramatic differences between closely held corporations and public corporations. However, nothing in federal securities law states, or even suggests, that a public offering alters the fundamental nature of share ownership. To the contrary, the terms of stock

184. See KLEIN \& COFFEE, supra note 26 , at 12 ("A ... customary approach would depict the owner as the core of the enterprise and the other elements as inputs hired by the owner and having only a very narrow interest in the enterprise."); id. at 5-6 (introducing sole proprietorships).

185. Cf. Dodd, supra note 140, at 1145-47 (discussing growth of firm in context of ownership).

186. UNIF. P'SHIP ACT § 6(1) (1914). See also REVISED UNIF. P'SHIP ACT § 101(6) (1997). The original and revised versions of the Uniform Partnership Act disagree on whether partners are coowners of partnership property. Compare UNIF. P'SHIP ACT $\$ 25$ ("A partner is co-owner with his partners of specific partnership property holdings. . ."), with REVISED UNIF. P'SHIP ACT § 501 ("A partner is not a co-owner of partnership property. ..."). However, they are in agreement that the partners are the co-owners of the partnership business. 
are governed by state law. The same laws apply to corporations regardless of whether they are closely or publicly held. ${ }^{187}$

What appear to be fundamental differences are nothing more than differing circumstances. A shareholder in a closely held corporation seems different than a shareholder in a public corporation because she is situated differently. Typically, she has a much larger percentage interest in the corporation. This affects her power and influence within the company. That her behavior would change as a result is unremarkable. But the difference is between shareholders, not corporations: in both public and closely held corporations, majority' shareholders will have control, minor shareholders will have very little power. ${ }^{188}$ Thus, a public offering does not transform the nature of share ownership.

Yet another candidate is based not on any particular action taken by the business, but on the level of involvement by shareholders. Perhaps shareholders lose their ownership claim when the corporation expands to the point that shareholders as a group are no longer involved in the management of the business. This corresponds roughly to the public offering explanation because shareholders in small businesses tend to be active participants whereas shareholders in public corporations tend to be passive investors. However, that is an oversimplification. Shareholders in a close corporation need not be actively involved in the business, and shareholders in a public corporation may very well be. The corporate governance mechanism is the same in both cases: shareholders elect directors (who may but need not be chosen from among themselves), and directors appoint officers (who may or may not be shareholders or directors). There are close corporations in which the shareholders hire others to run the business for them, and there are public corporations that are run by large shareholders. Thus, public status is a very crude proxy for shareholder involvement.

More importantly, involvement is a very poor determinant of ownership status. As a practical matter, it would be extremely difficult to specify a level of shareholder involvement that would be necessary to avoid forfeiture of the ownership interest. Similarly, there would be difficult issues concerning whether and how shareholders could reclaim their ownership interest by becoming more involved. Surely if one public corporation were to acquire another, the parent corporation should be

187. Some states have special statutes for closely held corporations. See, e.g., DEL. CODE ANN. tit. 8, §\$ 341-356 (2001). However, these provisions are optional. See, e.g., id. \$341(a). Closely held corporations can be incorporated under general corporation laws, and most of them are. See GEVURTZ, supra note $44, \S 5.2$, at $507 \&$ n. 84 .

188. I deliberately use the term "minor shareholder" instead of "minority shareholder" to avoid confusion. A minority shareholder is one who lacks a majority interest in a corporation. In a closely held corporation, a large minority shareholder can have absolutely no control if there is a majority shareholder. However, in a public corporation, a minority shareholder can have effective control if there are no other shareholders with similar holdings. By "minor shareholder," I mean one with a relatively insignificant interest such that they have no control, regardless of whether it be in a closely held corporation or a public corporation. 
considered an involved owner by almost any standard. However, the law never has required that owners be involved personally in the management of their assets. ${ }^{189}$ Thus, it would be anomalous to require involvement by shareholders.

Even if there were such a requirement, shareholders should be considered owners because they are involved in the management of the business. They elect directors, which is an exercise of direct control over the corporation as well as an exercise of indirect control over the business. In addition, members of top management in public corporations invariably are shareholders and often have significant holdings of the company's stock. Thus, at least some shareholders almost always are exercising direct control over the business.

There are other shareholder-based factors that could be said to change the nature of the equity interest. The size and duration of shareholder investments are two examples. Like involvement, however, these are poor determinants of ownership status. How much and how long would shareholders have to hold investments to be considered owners? Would ownership be assessed individually or collectively? In other situations, the law does not have such requirements for ownership. To be fair, there are not many situations in which ownership interests are divided as thinly as in public corporations. However, almost all shareholders own multiple shares, and often there are many shareholders with holdings of a size - a few percentage points - that is not uncommon in other situations. ${ }^{190}$ As for duration, there are plenty of situations where owners hold their assets for only short periods. For example, most retail products work their way through a number of distributors before reaching the ultimate consumer. Even real estate is often only a short-term investment, whether it is held for development or speculation. Flipping ${ }^{191}$ is a perfectly valid investment strategy that does not undermine ownership; shortterm ownership is limited only in duration. Finally, even if these factors were requirements of ownership, shareholders do satisfy them. The individual shareholder who frequently trades in individual shares is only one type of shareholder, and probably not a very common one. Much more common is the institutional investor with large holdings. In addition, many shareholders-individuals and institutions alike - follow an indexing strategy, pursuant to which they buy and hold securities. ${ }^{192}$ When in-

189. Adverse possession would be an exception. See SINGER, supra note 33, at 142 . However, an interest in a corporation cannot be adversely possessed.

190. To the extent that shareholders generally do not have larger holdings, it could be because federal law makes it difficult to do so. See Black, Shareholder Passivity, supra note 63, at 530-32.

191. Flipping is the process of "buy[ing] and then immediately resell[ing] securities or real estate in an attempt to turn a profit." BLACK'S LAW DICTIONARY 670 (8th ed. 2004).

192. Indexing is "[ $\mathrm{t}]$ he practice of investing funds to track or mirror an index of securities." Id. at 786. Because the index does not change very often, the investment strategy is essentially one of buy and hold. 
stitutional investors do this, as they often do, the result is large investments held for long periods of time.

In short, there is no point at which the equity holders of a business can be said to lose their ownership interests. Thus, it is difficult to conclude that they ever do. Every development in a business's life is a matter of degree rather than kind, and the underlying nature of the equity interest remains the same: every share represents partial ownership of the business. Of course, not all shareholders have an equal stake in the business, so some shareholders will be more powerful than others. But that is to be expected and in no way undermines the shareholders' collective ownership interest.

\section{Do Shareholders Consider Themselves Owners?}

Another common argument against shareholder ownership is based on the perceptions of shareholders themselves:

It is obvious that the average stockholder does not think of himself as a partial owner of the corporation, but as an investor free to move into and out of the corporation without loyalty, simply as a holder of an investment contract with different attributes from that of the bondholder. ${ }^{193}$

Implicitly, the argument continues: if shareholders do not even consider themselves to be owners, why should society consider them so? This argument has intuitive appeal. Under such circumstances, it seems more like a windfall to shareholders to acknowledge their ownership than like a loss to deny it.

The issue of shareholder belief is one that would benefit from empirical research. ${ }^{194}$ The claim that shareholders do not consider themselves owners generally is made without any supporting evidence. However, the claim is not at all obvious. To the contrary, I maintain that shareholders are part of the public which accepts the traditional view of the corporation..$^{195}$ Unfortunately, I too lack scientific evidence to support my claim. Nevertheless, personal anecdotal evidence strongly supports the claim that most people, whether or not they are shareholders themselves, believe that shareholders own the corporation. ${ }^{196}$ This

193. Homer Kripke, The SEC, Corporate Governance, and the Real Issues, 36 BuS. LAw. 173, 177

194. I have been able to find only one empirical study of shareholder opinion on the issue of ownership. It was a simple study conducted thirty years ago by Professors Soderquist and Vecchio. See Soderquist \& Vecchio, supra note 2. The study concluded that "shareholders expect to be treated as 'investors,' much like bondholders for example, and expect corporate managers to consider a wide constituency when making corporate decisions." Id. at 840 . However, the study did not purport to be scientific. In fact, the questions in the study were worded vaguely, and it is not clear whether participants would believe they were asked legal questions, common sense questions, or normative questions. Thus, the study is not very helpful for present purposes.

195. See supra text accompanying note 14 .

196. Most people I have asked believe that it is obvious that shareholders are the owners of the corporation, and are surprised to hear that there is any doubt. In fact, although I have come across 
should not be surprising. Most sources to which shareholders are exposed support the traditional view, either explicitly or implicitly. ${ }^{197}$ This is also true of many business and legal sources, including even educational texts. ${ }^{198}$ In fact, one of the key concepts that anyone who studies corporations will learn is the "separation of ownership and control"199which, by its very terms, suggests that shareholders are owners even though they are not managers. For shareholders to hear otherwise, they would have to read articles in scholarly journals. Needless to say, most shareholders probably do not do so very often.

In any event, the issue of what shareholders believe is irrelevant. Awareness is not a prerequisite to ownership. Although I believe that shareholders are aware of their status as owners, perhaps they are not. Even if that were the case, it would not be a basis for depriving them of their rights.

\section{WHY IT MATTERS}

Thus far, I hope to have established that there is more to the claim of shareholder ownership than academics generally admit. Contemporary criticism does more to highlight the weaknesses of the traditional view than it does to replace it, and there are strong reasons to believe that the traditional view remains descriptively accurate. But why does it matter? Why are claims of ownership, which may seem archaic and antiquated, so important? In this Part, I try to answer such questions.

On the most basic level, it is important because it (either) is (or is not) true. In the words of Professor Melvin Eisenberg, "what is at stake is simply getting things right; making sure that we employ a descriptive apparatus that is correct as a positive matter."200 As a student of the law, I care to know what it is that I am studying. The issue of ownership would be sufficiently of interest as a purely intellectual matter, even if its resolution were to have no consequences. In fact, however, it seems inconceivable that such a fundamental matter would be irrelevant as a practical matter. To the contrary, it likely would be extremely significant.

In this Part, I consider some of the ways in which ownership matters. Basically, it matters because it affects the allocation of rights in the corporation. First, I argue that, because property is a much more powerful concept than contract, shareholder rights are likely to be stronger and more secure if grounded in property than if grounded in contract. Then I

people who know nothing about corporations, I have not come across a nonacademic who actually believed shareholders were not owners.

197. See supra notes 14-18 and accompanying text.

198. See, e.g., BREALEY ET AL., supra note 82, at 3; MELVIN ARON EISENBERG, CoRPorATIONS AND OTHER BUSINESS ORGANIZATIONS 109 (9th ed. unabr. 2005).

199. See generally KLEIN \& COFFEE, supra note 26, at 177-85.

200. Eisenberg, supra note 118 , at 836. 
argue that, if shareholders are the owners of the corporation, corporate governance must reflect shareholder primacy. Finally, I argue that, if shareholders are owners, then directors serve the shareholders and adequate accountability is indispensible. In other words, the issue of ownership will have a significant impact on corporate law and the rights of all corporate stakeholders. Thus, the issue is important regardless of the normative desirability of shareholder rights. Advocates on both sides should be concerned, albeit for very different reasons.

\section{A. Foundation of Shareholder Rights}

The foundation of a right can have significant ramifications in terms of both interpretation and normative implications, and shareholder rights are no exception. If the traditional view is correct, shareholder rights are grounded in property law. If the nexus-of-contracts theory is correct, they are grounded in contract. In this Section, I argue that shareholder rights will be stronger and more secure under the traditional view than competing theories because of its grounding in property law. ${ }^{201}$

I begin with a simple and (hopefully) uncontroversial observation: that the source of a right will determine, to a great extent, how secure that right is. For example, all other things being equal, a constitutional right is more secure than a statutory right. This is because a legislature may repeal a statutory right freely, while a constitutional right may be repealed only by constitutional amendment. Similarly, a legal right is more secure than a contractual right because a contractual right depends entirely upon the parties while a legal right does not. Admittedly, the distinction between legal and contractual rights can be blurred by various considerations: for example, people generally have the legal right to the enforcement of contracts; in addition, many legal rights can be altered or waived by contract. However, contracts are not always entitled to enforcement, ${ }^{202}$ and many legal rules are mandatory. ${ }^{203}$ Moreover, property is an area of law that is particularly stable and resistant to change. ${ }^{204}$ Thus, a right grounded in property can be expected to be more secure than a right grounded in contract.

In addition, property law is significantly more robust than contract law. Property is a powerful legal concept in American law. An owner is a sovereign of sorts, with the power of control over the asset. Of course,

201. It is not clear what the source of shareholder rights would be under the communitarian theory. Therefore, I will not elaborate on the status of shareholders thereunder. It should suffice to note that, if shareholder rights are vulnerable under the contractarian theory, then they are up for grabs under the communitarian theory.

202. See infra notes $210-14$ and accompanying text.

203. See supra note 125 and accompanying text.

204. "In part because of its importance, property law is unusually resistant to legal change... Almost by definition ... property law resists changes to its contours for the very reason that change, as such, strikes at what decision makers typically view as one of its core traits." Eduardo Moisés Peñalver \& Sonia K. Katyal, Property Outlaws, 155 U. PA. L. Rev. 1095, 1133-34 (2007). 
an owner's rights may be limited by the law in various ways. However, an owner generally has a great deal of freedom to use the asset as she pleases. ${ }^{205}$ She also has the right to exclude others from the use of the asset. ${ }^{206}$ In fact, the Constitution even provides owners with rights against the state: in particular, property may not be taken without just compensation. ${ }^{207}$ This principle has been interpreted broadly enough that even regulation that goes too far may be considered a compensable taking. ${ }^{208}$ Finally, property rights generally are protected not only by liability rules, but also by stronger sanctions, including injunctive relief and criminal prosecution. $^{209}$

By comparison, contract is a much less powerful legal concept. Generally, competent individuals are free to enter into private arrangements. However, the Constitution does not protect the freedom of contract. There was a time-the Lochner era-when the Due Process Clause was interpreted to protect liberty of contract. ${ }^{210}$ However, the Supreme Court abandoned this interpretation during the New Deal era. ${ }^{211}$ The Constitution does provide that "No State shall... pass any ... Law impairing the Obligation of Contracts."212 However, as interpreted, the Contract Clause does not have much bite. ${ }^{213}$ Today, states are relatively free to regulate contractual arrangements. In fact, various laws regulate not only whether people may contract on a matter-e.g., criminal laws against prostitution - but also how they may do so-e.g., federal laws regulating the sale of securities - and the substantive terms of the contract - e.g., minimum wage laws. ${ }^{214}$ Moreover, these laws may change at any time, further weakening the right to contract. Of course, laws and changes in law can limit property rights as well. However, such changes tend not to be nearly as disruptive of property law as they are of contract law. A regulation may interfere with an owner's desired use of

205. Cf. SINGER, supra note 33 , at 3 ("Ownership does not mean the absolute right to control what one owns; rather, it is the fullest bundle of rights that the law will recognize.").

206. See generally Thomas W. Merrill, Property and the Right to Exclude, 77 NEB. L. REV. 730, 730 (1998) (arguing that "the right to exclude others is more than just 'one of the most essential' constituents of property-it is the sine qua non").

207. See U.S. CONST. amends. V, XIV, $\$ 1$.

208. "The Supreme Court has interpreted the takings clause to protect owners from fundamentally unjust alterations of their property rights by the state, including unjust limits on their ability to use their property as they wish." SINGER, supra note 33, at 676. See, e.g., Penn Cent. Transp. Co. v. New York City, 438 U.S. 104, 124 (1978) (setting forth a three-factor balancing test).

209. See, e.g., SINGER, supra note 33 , at 111 (describing injunctive relief as a nuisance remedy); id. at 92 (describing injunctive relief as a remedy for trespass to chattels); see also, e.g., FLA. STAT. ANN. $\S 810.09$ (West 2007 \& Supp. 2010) (describing criminal remedy for criminal trespass).

210. See Lochner v. New York, 198 U.S. 45, 53, 64 (1905).

211. See W. Coast Hotel Co. v. Parrish, 300 U.S. 379, 391 (1937).

212. U.S. CONST. art. I, $\$ 10$, cl. 1.

213. See Energy Reserves Group, Inc. v. Kan. Power \& Light Co., 459 U.S. 400, $410-11$ (1983). But see Henry N. Butler \& Larry E. Ribstein, The Contract Clause and the Corporation, 55 BROOK. L. REV. 767, 813-14 (1989).

214. E.g., Securities Exchange Act of 1934,15 U.S.C. $\$ 78 \mathrm{~b}$ (2006) (federal securities law); ALA. CODE § 13A-12-121 (LexisNexis 2005) (state law against prostitution); 820 ILL. COMP. STAT. 105/4 (1999 \& Supp. 2009) (state minimum wage law). 
his property, but it may not eliminate the ownership claim (at least, not without compensation). By comparison, a law may not only interfere substantially with a contract, it may invalidate the contract entirely. In other words, contracts exist at the whim of the legislature in a way that property does not. Finally, enforcement of contract law generally is limited to a liability rule. ${ }^{215}$ Thus, a right grounded in property can be expected to be stronger than a right grounded in contract.

Perhaps as important is the political dimension of property and contract. Property is a very powerful concept in American consciousness. Americans have always valued and respected property rights. ${ }^{216}$ In fact, they remain quite passionate about property rights. ${ }^{217}$ Despite what the experts have been saying for decades, Americans tend to have a very traditional understanding of property:

Most people... conceive of property as things that are owned by persons. To own property is to have exclusive control of something - to be able to use it as one wishes, to sell it, give it away, leave it idle, or destroy it. Legal restraints on the free use of one's property are conceived as departures from an ideal conception of full ownership. ${ }^{218}$

Legal experts often decry this powerful "mythology of property,"219 but even they cannot truly escape its grasp. ${ }^{220}$

Once again, contract is not nearly as powerful a concept. Of course, Americans generally appreciate the freedom of contract. However, they are accustomed to restrictions on and prohibitions against many types of

215. See George M. Cohen, The Fault that Lies Within Our Contract Law, 107 MICH. L. REV. $1445,1445-46$ \& n.1 (2009).

216. "In no other country in the world is the love of property keener or more alert than in the United States, and nowhere else does the majority display less inclination toward doctrines which in any way threaten the way property is owned." ALEXIS DE TOCQUEVILLE, DEMOCRACY IN AMERICA 638-39 (J.P. Mayer ed., George Lawrence trans., Anchor Books 1969) (13th ed. 1850); see also JAMES W. Ely, JR., THE GUARDIAN OF EVERY OTHER RIGHT: A CONSTITUTIONAL HISTORY OF PROPERTY RIGHTS 43 (1992) ("Despite their differences over particular economic issues, the right to acquire and own property was undoubtedly a paramount value for the framers of the Constitution."); Bret Boyce, Property as a Natural Right and as a Conventional Right in Constitutional Law, 29 LOY. L.A. INT'L \& COMP. L. REV. 201, 245 (2007); Stuart Bruchey, The Impact of Concern for the Security of Property Rights on the Legal System of the Early American Republic, 1980 WIS. L. REV. 1135, 1136.

217. The reaction to the recent Supreme Court decision in Kelo v. City of New London, 545 U.S. 469 (2005), attests to this fact. See Thomas W. MERRILl \& HENRY E. SMITH, ProperTY: PRINCIPLES AND POLICIES 1242-43 (2007) ("[T]he public repudiation of Kelo represents one of the most stunning instances of popular constitutionalism in our nation's history.").

218. Grey, supra note 35, at 69; see also ACKERMAN, supra note 37, at 97-100 (describing difference between scientific and ordinary/layman understanding of property).

219. See, e.g., Joan Williams, The Rhetoric of Property, 83 Iowa L. REv. 277,282 (1998) (internal quotation marks omitted) (quoting Milton C. Regan, Jr., Spouses and Strangers: Divorce Obligations and Property Rhetoric, 82 GEO. L.J. 2303, 2339 (1994)) (citing David Schultz, Political Theory and Le gal History: Conflicting Depictions of Property in the American Political Funding, 37 AM. J. LEGAL HisT. 464, 466 (1993)).

220. See Grey, supra note 35 , at 69 ("including most specialists in their unprofessional moments"); Williams, supra note 219 , at 278 ("[T]he intuitive image is the 'common sense' of layfolk and experts alike."). 
contracts. ${ }^{221}$ In fact, if only because of consumer protection laws, it is probably fair to say that they have come to expect regulation. Moreover, contract is not considered as inviolable as property: breach and default are not nearly as offensive to ordinary sensibilities as trespass or takings. ${ }^{222}$

In short, rights are likely to be stronger and more secure if grounded in property than in contract. Thus, it is important to know which account of the corporation is correct. If shareholder rights are grounded in contract, then they are more vulnerable than if they are grounded in property.

An additional reason why shareholder rights would be more vulnerable if based in contract is that they would not be inherent to the corporation, but solely a matter of voluntary exchange. As a result, they could be watered down in a number of ways. Obviously, shareholders may consent to reduced rights by approving a charter amendment to that effect. This is true under the traditional view as well. However, shareholder rights also may be abridged by operation of contracts with other stakeholders over which shareholders have no say. For example, a generous employment contract may reduce the value of the shareholders' residual interest, and a poison pill may limit a shareholder's ability to sell in a hostile takeover. Such interference with shareholder rights may be upheld under the business judgment rule, ${ }^{223}$ but at least are problematic if shareholders are owners. However, if the corporation is merely a nexus of contracts, then the fact that another contract could affect shareholders' residual rights not only would be perfectly legitimate, but should be expected.

In addition, corporate law itself can work against shareholder rights if, as contractarians suggest, default rules are based on hypothetical bargains. ${ }^{224}$ For example, if shareholders consistently forego a given right in exchange for consideration that either varies or is difficult to observe, then a default rule based on the majoritarian default likely would reflect an absence of the shareholder right without any corresponding compensation. By comparison, a property-based default rule would require compensation by requiring the exchange. In other words, corporate law based on contract risks undermining shareholder rights, while corporate law based on property only risks inefficiency.

Thus, the source of shareholder rights can make a huge difference. Ownership may not be absolutely necessary to protect shareholder

221. See, e.g., RESTATEMENT (SECOND) OF CONTRACTS $\$ 163$ (1981) (describing “When Misrepresentation Prevents Formation of a Contract"); id. $\$ 173$ (describing "When Abuse of a Fiduciary Relation[ship] Makes a Contract Voidable"); id. $\S 175$ (describing "When Duress by Threat Makes a Contract Voidable").

222. See Merrill \& Smith, Interface, supra note 40, at 776-77 (explaining that, while contracts "bind only the parties to the contract," property rights "bind 'the rest of the world").

223. See supra notes 65-68 and accompanying text.

224. See BAINBRIDGE, supra note 122, at 29-31. 
rights; contractarians believe that they can reach the same results through contract. However, ownership can be an important consideration. If shareholders are owners, then they are far less likely to be denied the kinds of rights generally associated with ownership.

\section{B. Shareholder Primacy}

One of the most important ways in which shareholder ownership matters is corporate governance. If shareholders own the corporation, then corporate governance must reflect this. In this Section, I argue that corporate governance must reflect shareholder ownership in terms of both end and means. Ownership may not provide an easy answer to every issue, or perhaps even to any particular issue. However, it will be at least a significant factor in determining the contours of corporate governance.

If shareholders own the corporation, then the end of the corporation is clear: to pursue the interests of shareholders. Property is the right of an owner to use an asset as she pleases, subject to any legal prohibitions. When there is a single owner, there is no need for a governance mechanism: whatever the owner says, goes. The need for a governance mechanism arises when there are multiple owners who may not agree on how to use the asset. As previously discussed, different options are available. ${ }^{225}$ The corporate form relies on a form of representative democracy: shareholders elect directors.

Under the traditional view, the pursuit of shareholder interests is the only end of corporate governance that makes sense. The very purpose of corporate governance is to facilitate decision making among the various and dispersed owners. The board of directors becomes the proxy for the shareholders. In a sense, it transforms the corporation into a virtual sole proprietorship. Thus, the pursuit of shareholder interests is as intrinsic to the governance of corporations as it is to the governance of sole proprietorships. ${ }^{226}$

By contrast, if there is no ownership claim on the corporation, then the goal of corporate governance is up for debate. Contractarians insist that the goal of shareholder wealth maximization can be secured without property, but this is not clearly correct. In the first place, if the corporation is merely a nexus of contracts, it is counterintuitive that the goal would be to pursue the interests of just one group of stakeholders. It seems much more plausible that the goal would be to pursue the interests of all of the corporate constituents, as communitarians insist. Of course, contractarians back their claim with many strong arguments grounded in

225. See supra notes $51-52$ and accompanying text.

226. It may be easier to change the goal of the corporation by legislative fiat than it would for the sole proprietorship because of the separation of ownership and control, but it would be equally inappropriate. 
efficiency. ${ }^{227}$ However, not everyone finds their arguments to be persuasive:

Communitarians.... reject the legitimacy of existing bargains by reference to power imbalances that make voluntary contracting impossible. They also ... reject the claims of efficiency made on behalf of shareholder primacy by denying the strength of the link between shareholder wealth and societal wealth [as well as] by insisting that the appropriate calculus of social welfare includes more than wealth. ${ }^{228}$

The greatest weakness of the contractarian argument is that it can only seek to persuade with policy arguments; it cannot compel with rights talk. People inevitably will disagree as to those policy considerations. Not only can people come to different conclusions as to what would be efficient, but they also can reject efficiency as the goal. Contractarians may consider this foolish, but they cannot consider it illegitimate. Thus, if shareholders are owners then the end of corporate governance is clear, but if they are not then it remains open to debate.

There is one potential problem that confronts the traditional view: the existence of constituency statutes, which allow directors to consider the interests of other stakeholders. ${ }^{229}$ I have considered constituency statutes in previous work, arguing that such legislation is fundamentally misguided and ineffective, ${ }^{230}$ and that adoption of constituency statutes has been less-than-universal and ultimately insignificant as a practical matter. ${ }^{231}$ Thus, I do not believe that constituency statutes are nearly as problematic as they could be theoretically. However, to the extent that they do pose a problem, the response of the traditional view is clear: provisions that attempt to deny or disparage the ownership rights of shareholders in a dramatic and fundamental way are illegitimate and perhaps even unconstitutional. ${ }^{232}$

At this point, it is worth noting that the goal of corporate governance should be understood broadly as facilitating the pursuit of shareholder interests rather than a more narrow pursuit of shareholder wealth maximization. ${ }^{233}$ Of course, wealth maximization is in the shareholder interests, and it is not unreasonable to consider the two generally interchangeable. However, shareholder interests can extend beyond wealth maximization. ${ }^{234}$ In fact, there may be times when other interests may

227. See Velasco, supra note 2, at 442-51.

228. Id. at 456 (footnote omitted).

229. See id. at $462-63 \&$ n.293 (describing and listing constituency statutes).

230. See id. at $463-64$.

231. See id.

232. See Oswald, supra note 130 , at 21-27 (describing takings argument against constituency statutes).

233. But see Dodge v. Ford Motor Co., 170 N.W. 668, 684 (Mich. 1919).

234. See, e.g., Ronald J. Colombo, Ownership, Limited: Reconciling Traditional and Progressive Corporate Law Via an Aristotelian Understanding of Ownership, 34 J. CORP. L. 247, 249 (2008) (pro- 
trump wealth maximization. For example, notions of justice and morality may cause shareholders to forego reprehensible behavior that would increase their wealth, even if such conduct is entirely legal. At other times, they may be willing to engage in charitable conduct. This would be perfectly legitimate-just as it would be for a sole proprietorship. ${ }^{235}$ Thus, shareholder primacy does hold open the potential for socially responsible behavior.

However, when the corporate purpose is extended beyond shareholder wealth maximization, it becomes important to ensure that shareholder interests are being pursued. There are at least two potential concerns. First, there is the issue of protecting the rights of shareholders who disagree. How should decisions of whether, and to what extent, shareholder wealth should be sacrificed for another purpose be made? Of course, similar problems arise with any democratic process, and majority rule generally is accepted as a reasonable solution. However, given that shareholders presume, quite reasonably, that the business will pursue profit, it may be necessary and appropriate for courts to scrutinize director decisions more closely as they diverge from shareholder wealth maximization. Second, there is the issue of director motivation. Directors should be permitted to forego shareholder wealth maximization only in the interests of shareholders, and consistent with their will. Directors should not be permitted to forego profit for their own purposes, whether it be out of altruistic concern for other constituencies or in order to benefit pet charities. Once again, given the potential for director misconduct, judicial supervision may be necessary and appropriate.

The means of corporate governance is a trickier issue. However, it should not be too controversial to assert that, if the shareholders own the corporation, the starting point (or null hypothesis) should be that shareholders should be able to control the corporation. Of course, with the corporate form, we quickly move away from this starting point. Corporations are controlled by directors. However, we must keep in mind the reasons for the move. It is not out of social concern, as communitarians might hope, so that the interests of the various stakeholders can be balanced by directors. Nor is it primarily out of paternalism, as some contractarians might believe, so that business experts can be put in charge. ${ }^{236}$ Rather, it is out of practical necessity: to accommodate numerous and dispersed shareholders. Communitarians and some contractarians view corporate governance as depriving the shareholders of control, but the

moting "an Aristotelian understanding of ownership" wherein owners act "in a way that is consistent with the common good").

235. Cf. EASTERBROOK \& FISCHEL, supra note 6, at 36 ("Our response ... is: who cares? If the New York Times is formed to publish a newspaper first and make a profit second, no one should be allowed to object.").

236. See, e.g., Blasius Indus., Inc. v. Atlas Corp., 564 A.2d 651, 663 (Del. Ch. 1988) ("The theory of our corporation law confers power upon directors as the agents of the shareholders; it does not create Platonic masters."). 
traditionalist knows that it is supposed to empower shareholders to exercise control indirectly.

Through their right to elect directors, shareholders have the ultimate say over the business - at least theoretically. Of course, having the ultimate say does not mean shareholders must have the final say on each and every issue. Delegation makes perfect sense, especially if the delegates are business experts. ${ }^{237}$ Nor does it necessarily mean that in every case, more shareholder power is necessarily better. Periodic, high-level control may be sufficient and, in many cases, superior to greater control. ${ }^{238}$ However, corporate governance rules must be about helping shareholders rather than protecting them from themselves, and about facilitating shareholders rather than impeding them. Thus, it may make sense to limit shareholder voice to the most important issues, but it does not make sense to impose a voting system that deprives them of any real say.

Let us consider shareholder voting rights in a little more detail. The fact that shareholders are owners does not necessarily tell us exactly what those voting rights should consist of. Issues such as how often elections should be held and what the voting standard should be must be answered in the light of various policy considerations. For example, annual elections are an obvious possibility, but staggered elections can have the advantage of promoting board continuity. Neither option is intrinsically better than the other. However, if it comes to pass that staggered boards regularly prevent shareholders from removing directors, then they become difficult to justify under the framework of the traditional view. Similarly, majority voting is an obvious candidate for the voting standard, but plurality voting can prevent the costs associated with ensuring the participation of rationally apathetic shareholders. ${ }^{239}$ However, if shareholders are not entirely apathetic and plurality voting regularly prevents them from replacing directors, then plurality voting becomes difficult to justify under the traditional view. Thus, ownership alone may not decide voting issues in the abstract, but it does influence the analysis significantly, and can limit the range of reasonable options in concrete circumstances.

By contrast, if shareholders are not the owners, then the means of corporate governance become debatable. The standard contractarian answer probably would be that the means of corporate governance would depend upon what the parties negotiated. Professor Bainbridge, however, argues in favor of director primacy: he believes directors should be pretty much free to decide how to pursue the goal of shareholder

237. See Velasco, supra note 2, at 441-42.

238. See KenNeth J. ARrow, The Limits of ORganization 77-79 (1974) (discussing "the trade-off between authority and responsibility [i.e., accountability]").

239. See Velasco, supra note 55, at 622-25. 
wealth maximization. ${ }^{240}$ Communitarians also believe in director primacy. However, because they reject the goal of shareholder wealth maximization, they believe directors should be free to balance the interests of various stakeholders. ${ }^{241}$ Other social responsibility theorists have proposed what could be considered a "stakeholder primacy" theory, where various stakeholders could have direct or indirect input into corporate decision making. ${ }^{242}$ As previously mentioned, the precise rules of corporate governance must be based on policy considerations. However, if shareholders are owners, the range of options is limited to those that would facilitate the pursuit of shareholder interests. By contrast, if there are no owners, those limits disappear, and the question of how corporations should be run becomes an open one.

Thus, the issue of shareholder ownership is important in the determination of both the end and means of corporate governance. It is possible for shareholder rights to be identical without an ownership claim; the same results might be reached by contract or policy considerations alone. However, ownership shifts the policy considerations decisively in favor of shareholders.

\section{Director Accountability}

In the previous Section, I argued that if shareholders own the corporation, the end and means of corporate governance must be shareholder primacy, whereas, if they are not, shareholder primacy is merely one possibility. In this Section, I argue that shareholder ownership has significant ramifications for director accountability as well. The basic argument is very simple and familiar: if shareholders are owners, then the directors work for them and should be accountable to them. Once again, shareholder ownership may not resolve any specific issue concerning the appropriate level of accountability, but it certainly will be a significant factor in the analysis.

Corporate law is very clear that directors have the authority to manage the business and affairs of the corporation consistent with their own business judgment. ${ }^{243}$ Broad director authority is an important value in corporate law. ${ }^{244}$ However, its value must be considered in context. Corporate law limits director authority in two important and related

240. See Bainbridge, supra note 20 , at $573-74$

241. See, e.g., Blair \& Stout, supra note 9, at 253.

242. See, e.g., RALPH NADER ET AL., TAMING THE Giant CoRporation 123-26 (1976); Lynne L. Dallas, Two Models of Corporate Governance: Beyond Berle and Means, 22 U. MiCH. J.L. REFORM 19, 107-12 (1988).

243. See supra notes $65-68$ and accompanying text.

244. See Aronson v. Lewis, 473 A.2d 805, 811 (Del. 1984) ("A cardinal precept of the General Corporation Law of the State of Delaware is that directors, rather than shareholders, manage the business and affairs of the corporation."). 
ways: first, by fiduciary duties, and second, by accountability mechanisms. ${ }^{245}$ Both are essential elements of corporate governance.

Although corporate law grants directors a great deal of discretion, it also charges them with fiduciary duties to pursue the interests of the shareholders. The one cannot be considered without reference to the other. Yet commentators often focus on director discretion and downplay fiduciary duties. The reason for this is the level of judicial deference afforded to director decisions under the business judgment rule. ${ }^{246}$ The standard is extremely permissive:

[W] hether a judge or jury considering the matter after the fact, believes a decision substantively wrong, or degrees of wrong extending through "stupid" to "egregious" or "irrational", provides no ground for director liability, so long as the court determines that the process employed was either rational or employed in a good faith effort to advance corporate interests. ${ }^{247}$

Thus, it is not unreasonable to characterize the business judgment rule as a policy of non-review rather than a standard of review. ${ }^{248}$ Because almost any business decision made by unconflicted directors will be upheld, it is not surprising that some commentators would suggest that directors are free to do as they please, without regard to shareholder interests. ${ }^{249}$ However, they are wrong.

Directors are not free to do as they please. They are required to pursue the interests of shareholders. As the Michigan Supreme Court stated famously long ago:

There should be no confusion .... A business corporation is organized and carried on primarily for the profit of the stockholders. The powers of the directors are to be employed for that end. The discretion of directors is to be exercised in the choice of means to attain that end, and does not extend to a change in the end itself, to the reduction of profits, or to the nondistribution of profits among stockholders in order to devote them to other purposes. ${ }^{250}$

Fiduciary duties require that the directors act in good faith in the best interests of the corporation and that they exercise the care of an ordinarily prudent person in a like position under similar circumstances. ${ }^{251}$ All of

245. DEL. CODE ANN. tit. 8, $\$ \$ 141,325,327$ (2001 \& Supp. 2008).

246. See supra note 68 and accompanying text.

247. In re Caremark Int'l Inc. Derivative Litig., 698 A.2d 959, 967 (Del. Ch. 1996); see also Brehm v. Eisner, 746 A.2d 244, 264 (Del. 2000) ("Irrationality is the outer limit of the business judgment rule.") (footnote omitted).

248. See Stephen M. Bainbridge, The Business Judgment Rule as Abstention Doctrine, 57 VAND. L. REV. $83,88-89$ (2004).

249. See, e.g., Blair \& Stout, supra note 9, at 299-305; D. Gordon Smith, The Shareholder Primacy Norm, 23 J. CORP. L. 277, 284-88 (1998).

250. Dodge v. Ford Motor Co., 170 N.W. 668, 684 (Mich. 1919); see also supra note 168.

251. See PRINCIPLES OF CORPORATE GOVERNANCE $\$ 4.01$, at 138-39 (1994); see also ModEL BUS. CORP. ACT \& 8.30(a)-(b) (2008). 
this is just as clear under corporate law as the breadth of director authority.

On the surface, these two sets of standards may seem contradictory. However, they are not; one is a standard of conduct and the other is a standard of review. ${ }^{252}$ "A standard of conduct states how an actor should conduct a given activity or play a given role. A standard of review states the test a court should apply when it reviews an actor's conduct to determine whether to impose liability or grant injunctive relief."253 The standard of conduct is primary. It sets forth the director's obligations. The standard of review merely determines how the fiduciary duty will be enforced. Thus, it is secondary and instrumental. The business judgment rule is lenient because, for various prudential reasons, the courts are hesitant to second-guess business decisions. ${ }^{254}$

If directors ... who violate the standards of [conduct] sometimes escape liability because of a less demanding standard of review, it is not because they have acted properly, but because utilizing standards of review that were fully congruent with the relevant standards of conduct would impose greater costs than the costs of letting some persons who violated their standards of conduct escape liability. ${ }^{255}$

That scholars would focus primarily on the standard of review is unfortunate..$^{256}$ Directors are not protected from liability so that they can ignore the interests of shareholders; to the contrary, it is so that they may pursue the interests of shareholders freely and aggressively. This immunity benefits shareholders by protecting them from overly risk-averse decision makers. However, judicial deference is premised upon trust in directors. If directors cannot be trusted-perhaps because they are led to believe that they can ignore the standard of conduct - then such judicial deference is wholly inappropriate. ${ }^{257}$ Because the business judgment rule is premised upon a healthy respect for fiduciary duties, scholars undermine the doctrine when they overemphasize it.

This leads to a discussion of accountability. According to former Delaware Chief Justice E. Norman Veasey, "[t]he defining tension in

252. See generally Melvin Aron Eisenberg, The Divergence of Standards of Conduct and Standards of Review in Corporate Law, 62 FORDHAM L. REV. 437 (1993).

253. Id. at 437.

254. See Julian Velasco, Structural Bias and the Need for Substantive Review, 82 WASH. U. L.Q. $821,830-33$ (2004) (discussing justifications for judicial deference under the business judgment rule); see also Eisenberg, supra note 252 , at $443-45$.

255. Eisenberg, supra note 252 , at $467-68$.

256. Communitarian reliance on the business judgment rule is especially ironic because it undermines their own goals. For example, Blair and Stout argue that the business judgment rule gives directors the freedom they need to balance the competing interests of stakeholders. Blair \& Stout, supra note 9, at 299-305. However, in order to do this, directors must be willing to ignore the legal standards of conduct. It is unclear why such directors, who consider themselves bound only by the standards of review, would follow the standards of conduct recommended by Blair and Stout rather than pursue their own interests.

257. See Velasco, supra note 254 , at $834-35$. 
corporate governance today is the tension between deference to directors' decisions and the scope of judicial review"258 - in other words, between authority and accountability. ${ }^{259}$ As I have argued elsewhere, balancing these competing interests means that neither can be ignored:

[The business judgment rule and the entire fairness test] provide complementary insights that are equally fundamental to corporate law: that, as a general matter, the interests of shareholders and directors are aligned such that directors can be trusted and need not be policed very closely, but that, when their interests conflict, directors cannot be trusted and must be subject to careful judicial scrutiny. Thus, the two standards represent opposite sides of the same coin. They are the twin pillars of enforcement of fiduciary duties in corporate law that provide balance between the competing values of authority and accountability. ${ }^{260}$

In almost every other context, the importance of accountability for decision makers is unquestioned. While there may be reasons to believe that corporate governance uniquely allows for reduced accountability ${ }^{261}$ it is important to maintain an adequate level.

In corporate law, accountability comes in two major forms: shareholder self-help and judicial intervention. Self-help should be relatively unobjectionable. Shareholders can protect themselves by selling their shares and by electing directors. Because the right to transfer is a standard right of ownership, shareholders should be able to sell their shares freely - at least presumptively. Restrictions on this right may be necessary, but they should be disfavored in light of the strong property law policy against restraints on alienation. ${ }^{262}$ The right to vote should be considered even more sacred. As a matter of property law, control is a standard right of ownership, and the election of directors is how shareholders exercise their control. Of course, some restrictions on the control of assets are always necessary. However, because it is the directors who exercise control over the corporate assets, legal restrictions should fall upon them rather than the shareholders. Moreover, as a matter of corporate law, the courts have recognized that " $[t]$ he shareholder franchise is the ideological underpinning upon which the legitimacy of directorial power rests."263 In other words, the shareholder right to elect directors is fundamental to corporate law. Thus, if shareholders are owners, restrictions on this right to vote are problematic and should be permitted only when necessary.

258. E. Norman Veasey, The Defining Tension in Corporate Governance in America, 52 BUS. LAW. 393, 403 (1997).

259. See Bainbridge, supra note 248 , at 84 .

260. Velasco, supra note 254 , at 826 .

261. See id. at 833-34.

262. See generally Restatement (SECOND) OF PROP.: DoNATtVE TRANSFERS $\S \S ~ 4.1-4.5$ (1983); SINGER, supra note $33, \$ 6.7 .2$, at 284-89.

263. Blasius Indus., Inc. v. Atlas Corp., 564 A.2d 651, 659 (Del. Ch. 1988); see also MM Cos. v. Liquid Audio, Inc., 813 A.2d 1118, 1128-29 (Del. 2003) (quoting Blasius, 564 A.2d at 659-63). 
Judicial intervention is a more complicated matter. This is because it involves not only shareholder action, but also judicial action. Society has the right to decide not to expend the resources necessary to vindicate each and every right fully. This could justify a standard of review that is more lenient than the standard of conduct. In addition, society could decide that judicial intervention is a poor way of effecting corporate accountability because courts are not business experts. ${ }^{264}$ This, too, could justify a lenient standard of review. However, there are times when even the imperfect tool of judicial intervention is superior to the alternativea lack of accountability for directors.

Exactly how much judicial intervention is appropriate is a policy question that cannot be answered merely by reference to shareholder ownership. In previous work, I have suggested where the lines could be drawn. ${ }^{265}$ This is not the venue to revisit such arguments. The point of the current discussion is simply that, if shareholders are owners, then the range of plausible answers is narrowed significantly. The relevant considerations are the benefits to shareholders and the costs involved. Thus, judicial intervention is less important when directors can be trusted to pursue the interests of shareholders and when shareholder self-help is effective; conversely, it is more important whenever directors cannot be trusted and when shareholders cannot protect themselves. However, if shareholders are not owners, then policy considerations can trump shareholder rights more easily.

In short, if shareholders are owners, then the directors work for them and shareholders will have the right to hold directors accountable. There may be reasons for limiting shareholder rights in specific ways, but not to the point where directors become unaccountable, as a legal or practical matter. Neither the directors themselves nor other stakeholders have a legitimate interest in reducing the accountability of directors for pursuing the interests of shareholders.

\section{CONCLUSION}

I now conclude with a more detailed account of the traditional view. Here, I attempt to synthesize various claims made throughout this Article in the form of an easily digestible narrative. In doing so, I hope to demonstrate not only that the traditional view is perfectly viable, but also why it is reasonable for those outside of the academy to adhere to it.

The central tenet of the traditional view is that the shareholders own the corporation. This view is widely held outside of the academy because it is fairly obvious. Businesses have owners: sole proprietorships have one owner; partnerships have multiple owners. Corporations may have as few as one owner, but may have many thousands. The form of

264. See Velasco, supra note 254 , at 831 \& n.30.

265. See id. at 870-87; Velasco, supra note 55, at 656-59. 
business organization is a legal technicality; there is nothing in it that necessarily affects ownership. Thus, the corporation is capable of being owned if the law says it is. And it would be anomalous for the law to say otherwise.

The concept of ownership is strongly implicit in our understanding of the corporation. For example, the corporation is nearly universally described as exhibiting a separation of ownership and control. Of course the phrase "separation of ownership and control" is not itself law, but only a description of the law which may or may not be accurate. However, its ubiquity is telling. On an even more basic level, shareholders own shares. The very term "shares" connotes an ownership interest; this is consistent with the use of the term with respect to partnerships. Shareholders are also said to hold the equity interest. This term also connotes ownership, as every homeowner will attest. To be fair, neither term is entirely free of ambiguity. Both terms could refer to an ownership interest in the assets of the business, for example. However, shareholders do not, in fact, own those assets; the corporation, as a separate entity, does. Alternatively, these terms could refer to ownership of the residual claim on the assets of the corporation. This would be consistent with the traditional view because, as owners, shareholders hold the residual claim. However, many academics would claim that shareholders own only the residual claim, and not the corporation itself. ${ }^{266}$ Yet there is no explanation for why the terms "shares" and "equity" are used in this limited respect only for corporations, and not for other forms of business organization. In fact, corporate statutes do not specifically provide that shareholders are residual claimants. If shareholders are, it is only because they are owners.

Of course, it is not sufficient to say that ownership is "obvious" and "implicit." We must look to what the law actually says. The Model Business Corporation Act, and the law of many states, explicitly provides that shareholders are indeed owners of the corporation. ${ }^{267}$ The Delaware General Corporation Law contains no such provision. However, the Delaware courts have understood this to be the case. ${ }^{268}$ Moreover, the Delaware Supreme Court recently has reaffirmed the traditional view as the basis for the rules regarding derivative litigation. ${ }^{269}$ Thus, the law does provide that shareholders are owners.

But perhaps the law is wrong. After all, shareholders do not resemble owners in many respects. For example, it is often argued that shareholders do not have control, one of the most important aspects of ownership. ${ }^{270}$ However, shareholders do have control. This is most obviously

266. See supra note 20 and accompanying text.

267. See supra notes $162-64$ and accompanying text.

268. See supra notes $166-82$ and accompanying text.

269. See supra note 157 and accompanying text.

270. See supra notes 54-55 and accompanying text. 
true when there is only one shareholder. When a sole proprietor incorporates his business, no one doubts that he has control and remains the owner. Similarly, no one doubts that a parent corporation controls, and owns, its (wholly owned) subsidiaries. Thus, the ultimate power of control does reside in the shareholders.

It is often argued that public corporations present a very different circumstance. ${ }^{271}$ Dispersed shareholders have very little control over the corporation legally, and almost none in fact. However, this simplistic observation fails to appreciate the complexity of corporate structure. It is true that shareholders have little direct power over the corporation. But this is because dispersed shareholders cannot be expected to manage the business effectively. Thus, the law provides that shareholders elect directors to manage the business on their behalf. Shareholders are free to elect directors from among their own numbers, but they are not required to do so. In any event, through the directors - their elected representatives - the shareholders exercise indirect control over the corporation.

It is often argued that the extent of director authority undermines the shareholders' ownership claim: the directors have direct control over the corporation, and the business judgment rule ensures that they will not be held accountable for almost any decision. ${ }^{272}$ However, this is another oversimplification. Judicial intervention is only one means of holding directors accountable. Shareholders can also engage in self-help through the use of their two fundamental rights: the right to vote and the right to sell shares. It is de rigueur to note that the shareholder right to vote is extremely weak. However, recent developments have shown that the right is not nearly as weak as often was believed. ${ }^{273}$ In addition, shareholders have the right to sell their shares. As dissatisfied shareholders sell their shares in increasing numbers, the value of the corporation drops. This not only sends a clear signal to management but also subjects them to the risk of a hostile takeover. At least in extreme cases, the market for corporate control is capable of returning power to the shareholders.

Moreover, the role of the judiciary in corporate governance is often misunderstood. It is the role of the judiciary "to say what the law is."274 The courts tell us that directors are bound to use their powers to pursue the best interests of the corporation and its shareholders. More specifically, under the duty of care directors must make informed decisions, and under the duty of loyalty they must avoid conflicts of interest. This is what defines the role of directors; this is what is expected and demanded of them. Enforcement is a separate matter. Because judges are not business experts, and because they understand the nature of risk and

271. See supra Part II.B.

272. Velasco, supra note 2, at 430 .

273. Id. at 419-20.

274. Marbury v. Madison, 5 U.S. (1 Cranch) 137, 177 (1803). 
hindsight bias, they are not inclined to intervene in business affairs except when necessary. The business judgment rule is essentially a litigation management device. It shields the substance of business decisions from judicial review almost entirely and provides a strong presumption that the duty of care has been satisfied. However, when the duty of loyalty is at stake, the courts engage in much more exacting review under the entire fairness test. ${ }^{275}$ This structure makes sense, given the institutional limitations of the courts: when directors can be trusted, judicial review is unnecessary and perhaps harmful, but when directors cannot be trusted, judicial review becomes necessary. The beneficial consequence of this structure is that directors are free to exercise their business judgment without fear of liability. There is, however, an unfortunate consequence: directors can get away with almost anything, provided only that they avoid the appearance of self-dealing. From this unfortunate side effect, academics sometimes argue that directors are free to do as they please. ${ }^{276}$

Of course, directors are not free to do as they please. They are not free to engage in self-dealing, which is where the true risk of misbehavior lies. At most, they are free to choose to benefit other stakeholders at the expense of shareholders. Social responsibility theory ultimately depends upon this sort of altruism: directors are expected to ignore the mandates of law and the rights of shareholders in order to benefit not themselves, but other stakeholders. One might not be considered unreasonable for concluding that this risk is a relatively minor one. Besides, directors could do even this only through subterfuge. If directors were to admit that they were setting aside the short-term and long-term interests of shareholders and pursuing the interests of other stakeholders as such (in a significant way), then their decisions would not be upheld by the courts. Constituency statutes notwithstanding, the law is clear: directors are free to choose among means, but not among ends. As a practical matter, regardless of what they do, directors always maintain the façade of pursuing the long-term interests of the shareholders in order to preserve the presumption of the business judgment rule. Thus, even if directors are able to get away with doing as they please, they are not legally "free" to do so.

The fact that directors theoretically may be able to get away with significant misconduct does not impugn shareholder ownership. It is merely the result of imperfect enforcement. But, of course, the law is always enforced imperfectly. Perfect enforcement is prohibitively expensive. Thus, society (or the government) must always decide upon an appropriate level of enforcement, whether explicitly or implicitly. If the business judgment rule is too lax, then it ought to be revised. Likewise, the entire fairness test may be too lax, or perhaps too strict. I tend to be-

275. See supra Part IV.C.

276. See supra note 248 and accompanying text. 
lieve that both are more-or-less appropriate, at least in principle (although, as I have argued elsewhere, I believe that there is a need for a revised intermediate standard of review to deal with cases of structural bias). But the broader point is this: the law of fiduciary duties is clear as to the standard of conduct, and if the standards of review provide inappropriate levels of enforcement, then they should be reconsidered.

Finally, it might be argued that directors owe their fiduciary duties not the shareholders, but to the corporation as a separate entity. This is not a fair statement of the law. Courts generally acknowledge that directors owe their fiduciary duties to the corporation and its shareholders. ${ }^{27}$ In any event, it does not make much difference. If fiduciary duties are owed to the corporation as a separate entity, then that entity is distinct not only from the shareholders but also from all of its constituents. In other words, directors must treat the corporation as a separate entitylike a sole proprietorship of sorts - and maximize its wealth, and not the collective wealth of the various stakeholders. This corporate wealth ultimately redounds to the benefit of the shareholders who, as owners, hold the residual claim on the corporate assets.

Once it is established that shareholders are owners, certain consequences follow. Most importantly, their status as owners becomes secure. They cannot be denied that status without just compensation. Moreover, the role of corporate governance becomes clear: it is to facilitate shareholder primacy in terms of both ends and means. This does not mean that shareholders must be given direct control; effective indirect control may be sufficient and even superior as a practical matter. Nor does ownership provide a necessary answer for any particular question of corporate governance. Any number of rules may be perfectly acceptable, provided that they do not stand in the way of shareholder primacy. Finally, if directors are the elected representatives of the shareholders, then it is appropriate for them to be accountable to the shareholders. Again, the particular rules by which they might be held accountable can be subject to debate. However, they cannot be veiled efforts to shield directors from accountability.

In short, if the traditional view is correct, then shareholders are owners and corporate governance must be primarily about them and their interests. However, if shareholders are not owners, then there is room to discuss whether contractarians or communitarians have the better policy arguments. Either way, the issue of shareholder ownership is a central one for corporate law.

277. See supra note 154 and accompanying text. 